\title{
Capacidad jurídica en el nuevo artículo 3 del Código Civil
}

\section{Aníbal Torres Vásquez}

Abogado por la Universidad Nacional Mayor de San Marcos. Doctor en Derecho y Ciencias Políticas por la Universidad Nacional Mayor de San Marcos.

Ex Decano de la Facultad de Derecho y Ciencias Políticas de la Universidad Nacional Mayor de San Marcos. Ex Decano del Colegio de Abogados de Lima.

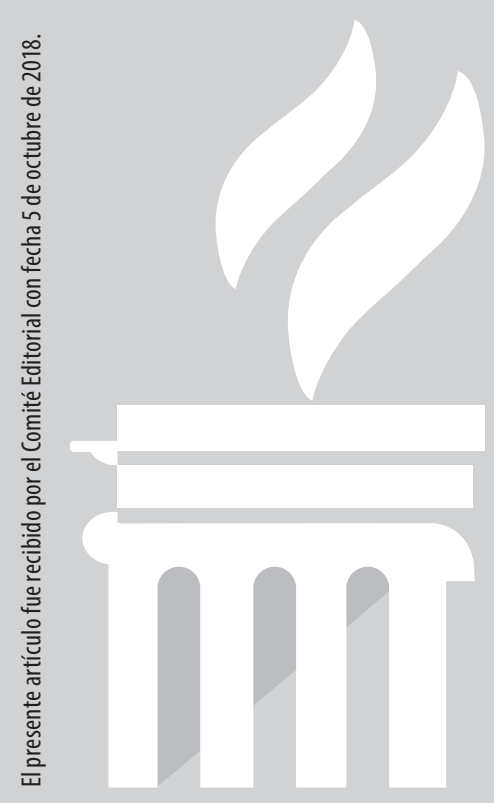

SUMARIO:

I. Persona, personalidad y subjetividad jurídica.

II. Capacidad jurídica.

1. Concepto de capacidad de goce.

2. El nacimiento como requisito para que la persona humana adquiera su plena capacidad de goce.

3. Limitaciones a la capacidad de goce.

4. Doctrina que considera que no es posible que el derecho pueda limitar la capacidad de goce. Crítica.

5. Capacidad de ejercicio de las personas con discapacidad. 


\title{
RESUMEN:
}

En el presente artículo, el autor realiza un profundo análisis sobre el tratamiento jurídico que el Derecho ha otorgado al ser humano para ser titular de derechos y deberes. Sostiene que el ordenamiento jurídico al estar encargado de reconocer los derechos de las personas, puede limitar o privar determinados derechos para salvaguardar una coexistencia social civil pacífica. Asimismo, establece el autor que, al ser nuestro país parte de la Convención sobre los Derechos de la Personas con Discapacidad y en aras de construir una sociedad justa y respetuosa, es esencial que el Estado garantice las adaptaciones legales y políticas necesarias para que las personas con discapacidad puedan realizarse como personas con plenos derechos.

Palabras clave: Personalidad jurídica, capacidad de goce, capacidad de ejercicio, ordenamiento jurídico, coexistencia social civil pacífica, inclusión social, discapacitados.

\begin{abstract}
:
In this article, the author makes a deep analysis on the legal treatment that the Law has given to the human being in order to be a holder of rights and duties. He argues that the legal system, being in charge of recognizing the rights of individuals, can limit or deprive certain rights in order to safeguard a peaceful civil social coexistence. Likewise, the author establishes that, since our country is a party to the Convention on the Rights of Persons with Disabilities and in the interest of building a fair and respectful society, it is essential that the State guarantees the necessary legal and political adaptations so that persons with disabilities can realize themselves as persons with full rights.

Keywords: Legal personality, capacity to enjoy, capacity to exercise, legal order, peaceful civil social coexistence, social inclusion, disabled.
\end{abstract}

\section{Artículo 3.- Capacidad jurídica.}

Toda persona tiene capacidad jurídica para el goce y ejercicio de sus derechos.

La capacidad de ejercicio solo puede ser restringida por ley. Las personas con discapacidad tienen capacidad de ejercicio en igualdad de condiciones en todos los aspectos de la vida.'

\section{PERSONA, PERSONALIDAD Y SUBJETIVI- DAD JURÍDICA}

No todo ser humano es persona, sino solamente a partir de su nacimiento. La persona termina con la muerte.

La personalidad es el conjunto de características que diferencian a una persona de las demás; es obra de la naturaleza y de factores sociales.

La personalidad jurídica es conferida por el Derepor ley. do y libremente a los demás entes para ser sujetos de relaciones jurídicas, o sea de derechos subjetivos y de deberes jurídicos. Es el presupuesto para la producción de determinados efectos jurídicos previstos por la norma en cabeza del sujeto.

La subjetividad jurídica es la abstracta aptitud para ser titular de derechos y deberes. Es atribuida por el ordenamiento jurídico no solamente a las personas físicas sino también a colectividades de personas constituidas o no en personas jurídicas, a masas patrimoniales privadas transitoriamente sin titular, entre otros entes.

La capacidad de goce es la aptitud del sujeto de derecho para ser titular de derechos y deberes. Tiene como presupuesto a la existencia del sujeto.

La capacidad de ejercicio - o de obrar o de actuar- es la aptitud para el ejercicio de los derechos subjetivos y de los deberes jurídicos. Tiene como presupuesto a la capacidad de goce.

1. Texto modificado por el Decreto Legislativo 1384, publicado el 4 de septiembre de 2018. El texto original decía: Artículo 3. Toda persona tiene el goce de los derechos civiles, salvo las excepciones expresamente establecidas 
El Título II del Libro I del Código Civil se denomina Derechos de la Persona, olvidando que en el artículo 1 se distingue entre concebido y persona humana como dos sujetos diferentes de derecho. Los derechos mencionados en este Título no competen únicamente al ser humano desde su nacimiento sino desde su concepción, por lo que se hace necesario modificar o bien el artículo 1 en el sentido de considerar al ser humano como persona desde su concepción o bien cambiar la denominación del Título II del Libro I. Es innegable que la existencia del ser humano comienza con la concepción y termina con la muerte.

Desde el punto de vista filosófico todo ser humano es persona, pero no lo es desde la perspectiva del Derecho. En Derecho el concepto de persona es metajurídico, tomado desde fuera del Derecho, solamente es persona aquel al cual el Derecho positivo le reconoce personalidad si cumple con determinados requisitos en un momento histórico y en una circunstancia geográfica. Veamos algunos ejemplos:

a) El Código de Andrés Bello adoptado por los códigos de Chile -1855-, artículo 74, y Colombia -1887-, artículo 90, dispone:

"La existencia legal de toda persona principia al nacer, esto es, al separarse completamente de su madre. La criatura que muere en el vientre materno, o que perece antes de estar completamente separada de su madre, o que no haya sobrevivido a la separación un momento siquiera, se reputará no haber existido jamás".

b) El Código español:

"Artículo 29. El nacimiento determina la personalidad; pero el concebido se tiene por nacido para todos los efectos que le sean favorables, siempre que nazca con las condiciones que expresa el artículo siguiente. artículo 30. Para los efectos civiles, sólo se reputará nacido el feto que tuviere figura humana y viviere veinticuatro horas enteramente desprendido del seno materno."

c) El Código ecuatoriano modificó al de Andrés Bello en los términos siguientes:
"Artículo 60. El nacimiento de una persona fija el principio de su existencia legal, siempre que viva veinticuatro horas a lo menos desde que fue separada completamente de su madre. La criatura que muere en el vientre materno, o que perece antes estar completamente separada de su madre, o que no haya sobrevivido a la separación veinticuatro horas a lo menos, se reputará no haber existido jamás".

d) En el Perú:

El Código de 1852 estableció:

"Artículo 1. El hombre, según su estado natural, es nacido o por nacer. 2. El hombre desde que nace, tiene los derechos que le declaran las leyes. 3. Al que está por nacer se le reputa nacido para todo lo que le favorece. 4. El nacido y el que está por nacer necesitan para conservar y trasmitir estos derechos que su nacimiento se verifique pasados seis meses de su concepción, que viva cuando menos veinticuatro horas y que tengan figura humana".

El artículo 1 del Código de 1936 señaló:

"El nacimiento determina la personalidad. Al que está por nacer se le reputa nacido para todo lo que le favorece, a condición de que nazca vivo".

El vigente Código de 1984 señala:

"Artículo 1. La persona humana es sujeto de derecho desde su nacimiento. La vida humana comienza con la concepción. El concebido es sujeto de derecho para todo cuanto le favorece. La atribución de derechos patrimoniales está condicionada a que nazca vivo".

e) El Código Civil y Comercial argentino, vigente desde el 1 de agosto de 2015, prescribe:

"Artículo 19. La existencia de la persona humana comienza con la concepción."

Se aprecia que en la legislación comparada no hay uniformidad sobre los requisitos exigidos para reconocer personalidad jurídica al ser hu- 
mano: para unos se requiere que al nacer se "separare completamente de su madre"; para otros, que "sólo se reputará nacido el feto que tuviere figura humana y viviere veinticuatro horas enteramente desprendido del seno materno"; otros establecen "que su nacimiento se verifique pasados seis meses de su concepción, que viva cuando menos veinticuatro horas"; hay los que exigen el que "nacimiento se verifique pasados seis meses de su concepción, que viva cuando menos veinticuatro horas y que tengan figura humana"; finalmente, unos consideran que se es persona a partir del nacimiento y otros, a partir de la concepción. Es el Derecho el que reconoce personalidad jurídica al ser humano.

Queda demostrado que las expresiones "ser humano" y "persona" no son sinónimas; el ser humano es anterior al Derecho, constituye el principio y el fin de este. La calificación de "persona" no solo es atribuida por el ordenamiento jurídico al individuo nacido - persona natural o física-, sino también al conjunto de personas organizadas para un fin común, cuya existencia comienza al siguiente día de su inscripción en el registro respectivo, que para diferenciarlo de la "persona física" se le denomina "persona natural".

Para Kelsen², la "persona" es solo una expresión unitaria personificadora para un haz de deberes y facultades jurídicas, es decir, para un complejo de normas; "la persona física" no es el hombre, no es un concepto jurídico, sino biológico-psicológico. No expresa unidad alguna dada al Derecho, pues el Derecho no aprehende al hombre en su totalidad, con todas sus funciones anímicas y corporales; solo estatuye actos humanos bien determinados, como deberes o facultades. Si ha de distinguirse el concepto científico-natural del hombre del concepto jurídico de persona, esto no significa que "la persona" sea una especie particular del hombre, sino que ambos representen dos unidades completamente diferentes.
El concepto jurídico de persona o de sujeto del Derecho expresa solamente la unidad de una pluralidad de normas que estatuyen esos deberes y derechos.

"Que el hombre sea o tenga personalidad jurídica no significa en último término otra cosa sino que ciertas acciones $u$ omisiones suyas constituyen, en una u otra forma, el contenido de normas jurídicas. Con respecto a la distinción rigurosamente mantenida entre hombre y persona, es incorrecto, por tanto, decir que el Derecho obliga y faculta a personas. Obligados y facultados son los hombres. Es conducta humana lo que constituye el contenido de las normas jurídicas $y$, por ende, el contenido de los deberes y los derechos; y la conducta humana no puede ser otra cosa que conducta de hombres individuales".

No compartimos la teoría de Kelsen cuando en el extremo que afirma que solamente el hombre individual puede ser centro de imputación de derechos y deberes, puesto que el Derecho atribuye derechos y deberes a otros entes tales como; el concebido - artículo 1-, las personas jurídicas —artículo 76 y subsiguientes-, las organizaciones de personas no inscritas —artículo 124 y subsiguientes-, la sociedad conyugal —artículos 287 y subsiguientes-, la sociedad de gananciales —artículo 301-, las uniones de hecho entre un varón y una mujer -artículo 326-, las sociedades reguladas por la Ley General de Sociedades — Ley 26887-, entre otros.

La personalidad ${ }^{3}$ - sin ninguna calificación jurídica- es el conjunto de características que diferencian a una persona de las demás; es obra de la naturaleza y de factores sociales.

La personalidad jurídica es la atribución, necesaria para el ser humano y libre para los demás entes, conferida por el Derecho objetivo al sujeto de derecho para ser titular de relaciones

2. KELSEN, Hans. La teoría pura del Derecho. Introducción a la problemática científica del Derecho. Segunda Edición. Buenos Aires: Losada, 1946, p. 83. 
jurídicas, o sea de derechos subjetivos y de deberes jurídicos. Es obra del ordenamiento jurídico. Algunos autores dicen que la personalidad jurídica del individuo es atribuida por la naturaleza y reconocida por el ordenamiento jurídico ${ }^{4}$. No podemos admitir esta opinión por cuanto la naturaleza no hace calificaciones jurídicas, sino solamente la norma jurídica por más insipiente que sea; por ello, hablamos de atribución y no de reconocimiento de la personalidad jurídica al ser humano. Es el presupuesto necesario para la producción de determinados efectos jurídicos previstos por la norma en cabeza del sujeto.

La personalidad jurídica es la expresión de la función creadora del Derecho con el fin de resolver un problema fundamental de organización social. Afirma Pastori ${ }^{5}$ que la personalidad jurídica atribuye, en determinado ordenamiento jurídico, la calificación de persona, condición para devenir en parte activa o pasiva de relaciones jurídicas, como, por ejemplo, las relativas a la propiedad, al crédito, a la herencia. Otros autores identifican a la personalidad jurídica con la capacidad de goce, o sea la aptitud de ser sujeto de relaciones jurídicas — subjetividad jurídica-. Por efecto de la personalidad jurídica se es sujeto de derecho.
A la relación creada por el Derecho positivo entre sujeto y sujeto, atribuyendo a uno un derecho subjetivo y al otro el deber jurídico corelativo, se le denomina relación jurídica. A la capacidad del sujeto para ser titular de relaciones jurídicas, o sea de derechos y deberes jurídicos, se le llama personalidad jurídica. Por tanto, la personalidad jurídica es el presupuesto necesario de la producción de determinados efectos jurídicos previstos por la norma para el sujeto.

No existe una sino varias acepciones de personalidad jurídica. Unos la identifican con la persona, verbigracia, cuando se dice "el nacimiento determina la personalidad" ${ }^{\prime \prime}$; otros, con la capacidad de goce ${ }^{7}$. Según Kelsen ${ }^{8}$, solamente el hombre tiene personalidad:

"Que el hombre sea o tenga personalidad jurídica no significa en último término otra cosa sino que ciertas acciones $u$ omisiones suyas constituyen, en una $u$ otra forma, el contenido de las normas jurídicas".

Se afirma que la personalidad jurídica del hombre es reconocida y no atribuida por el ordenamiento jurídico al sujeto: "La personalidad jurídica del hombre no puede menos de ser reconocida; la atribución es obra de la naturaleza misma",

3. Diccionario de la Real Academia Española: "Personalidad. -De personal-. 1. f. Diferencia individual que constituye a cada persona y la distingue de otra. 2. Conjunto de características o cualidades que destacan en algunas personas. Andrés es un escritor con personalidad. 3. Persona de relieve, que destaca en una actividad o en un ambiente social. Al acto asistieron el gobernador y otras personalidades. 4. Inclinación o aversión que se tiene a una persona, con preferencia o exclusión de las demás. 5. Dicho o escrito que se contrae a determinadas personas, en ofensa o perjuicio de las mismas. 6. Der. Aptitud legal para intervenir en un negocio o para comparecer en juicio. 7. Der. Representación legal y bastante con que uno interviene en él. 8. Fil. Conjunto de cualidades que constituyen a la persona o supuesto inteligente."

4. Por ejemplo, BARBERO, Domenico. Sistema del Derecho privado. Traducción de Santiago Sentis Melendo. Buenos Aires: Ejea, 1967, p. 192.

5. PASTORI, Franco. Gli istituti romanistici come storia e vita del diritto. Segunda Edición. Milán: Cisalpino-Goliardica, 1988, p. 40.

6. Artículo 29 del Código español.

7. Por ejemplo, ENNECCERUS, Ludwig, KIPP, Theodor y WOLFF, Martin. Tratado de Derecho Civil. Tratado de PÉREZ, Blas y ALGUER, José. Parte general. Tomo I. Vol. I. Segunda Edición. Bosch: Barcelona, 1953, p. 328. En esta página el autor dice que "la personalidad no es un derecho subjetivo, sino una cualidad jurídica, que constituye la condición previa de todos los derechos y deberes; equivale a la capacidad jurídica".

8. KELSEN, Hans. Op. Cit., p. 85. 
mientras que para otros entes es la atribución del ordenamiento jurídico ${ }^{9}$. Se sostiene que la personalidad jurídica es la aptitud o idoneidad para ser titular de derechos. El profesor Fernández Sessarego ${ }^{10}$ expresa que la personalidad:

"es la manera como se presenta o manifiesta el ser humano nacido en la vida social", es decir, "la realización concreta de la persona en el mundo fenoménico, a través de conductas humanas intersubjetivas"; "no se trata de otra cosa que el despliegue factual de la libertad".

Agrega Fernández Sessarego que dada a la confusión terminológica se eliminó la palabra "personalidad" del texto del proyecto de del Código Civil de 1984 dedicada al derecho de las personas. Anotamos que no todas las conductas humanas intersubjetivas son jurídicas ${ }^{11}$, sino solamente las reguladas por el Derecho por ser posibles en un determinado lugar y época.

En el Derecho comparado, los distintos ordenamientos jurídicos y los tratados internacionales de los cuales el Perú es parte se refieren a la personalidad jurídica, lo que obliga a tratarla someramente en este trabajo.

La personalidad jurídica es una creación del Derecho y se manifiesta en la aptitud que se tiene para ser sujeto titular de derechos y deberes jurídicos, lo que determina la capacidad para relacionarse jurídicamente. De esto se derivan dos tipos de capacidad: la de goce y la de ejercicio. La segunda presupone la primera. Para decir, que la noción de persona, y no la de vida humana, proviene de la naturaleza habría que borrar todo el Derecho positivo desde el Derecho romano hasta la actualidad en cuanto reconoce personalidad jurídica al ser humano; es más habría que negar la existencia de la esclavitud en épocas pasadas, al esclavo no se le reconoció personalidad jurídica, no era sujeto sino objeto de derecho; o habría que negar la supresión de la personalidad con la aplicación de la pena de muerte civil en épocas pasadas. Decimos que la esclavitud ha desaparecido de la faz de la tierra, así es, pero solamente en el mundo civilizado, más no en el que no lo es, pensemos en el secuestro de mujeres, especialmente menores de edad, para dedicarlas a la prostitución en los centros de explotación minera ilegal en la selva de Madre de Dios, mujeres privadas de sus derechos y libertades fundamentales, con un Estado corrupto incapaz de evitarla, una población indolente que la tolera y unos teóricos del Derecho, que olvidándose del fin que persigue este, lo utilizan para crear, modificar o derogar normas para satisfacer sus egos personales.

Todos los seres humanos son iguales en dignidad y derecho, sin distinción por razones de raza, color, sexo, idioma, religión, nacionalidad o posición social, económica, política o de cualquier otra índole. "Todo ser humano tiene derecho, en todas partes, al reconocimiento de su personalidad jurídica" —artículo 6 de la Declaración Universal de Derechos Humanos-. La personalidad jurídica, es decir, la capacidad para ser titular de derechos y deberes, es reco-

9. BARBERO, Domenico. Op. Cit., p. 192. No participamos de la opinión de Barbero, porque la naturaleza no hace calificaciones jurídicas, sino solamente el Derecho, por tanto, la naturaleza no atribuye personalidad jurídica sino el Derecho objetivo.

10. FERNÁNDEZ SESSAREGO, Carlos. El Derecho de las personas (En el umbral del siglo XXI). Ediciones Jurídicas. Lima: 2002 , p. 376.

11. En toda relación jurídica existe un elemento material, un hecho social, y un elemento formal o sea aquel por el cual la relación fáctica es elevada a la forma jurídica. "Pero no todas las relaciones entre hombres pertenecen al campo jurídico, siendo susceptibles y necesitadas de tal determinación por reglas jurídicas. Podemos distinguir en este aspecto tres casos: relaciones humanas que pertenecen al campo jurídico o que son dominadas por reglas jurídicas, por completo; otras que no lo son en absoluto; y otras, finalmente, que solo lo son en parte. Pueden figurar como ejemplo de la primera clase la propiedad, de la segunda la amistad y de la tercera el matrimonio, puesto que el matrimonio en parte pertenece al campo jurídico y en parte trasciende de él". VON SAVIGNY, Friedrich, KIRCHMANN, Julius, ZITELMANN, Ernst y KANTOROWICZ, Hermann. La ciencia del Derecho. Buenos Aires: Losada, 1949, p. 183. 
nocida por el Derecho positivo al ser humano por el solo hecho de existir sin necesidad de su aceptación. El artículo 1 de la Constitución prescribe: "La defensa de la persona humana y el respeto de su dignidad son el fin supremo de la sociedad y del Estado".

El ser humano, considerado individualmente u organizado colectivamente, es el protagonista de las relaciones jurídicas, y quien goza de los derechos subjetivos y está sujeto a los deberes establecidos por el ordenamiento jurídico. El ser humano es el creador y destinatario de las normas jurídicas - Derecho positivo-. Al percibir la necesidad de algunas reglas de organización que gobiernen la convivencia entre los individuos se crea el Derecho. Éste ordena la conducta de los individuos restringiendo de algún modo su libertad, reconociéndoles su dignidad como personas y prestándoles su decidida e incondicional tutela.

El problema de organización es resuelto por el Derecho mediante un criterio valorativo, variable — con el tiempo y con el espacio- en cada ordenamiento jurídico, de la aptitud de los individuos y de los grupos sociales para asumir la calidad de sujetos de Derecho. Por ejemplo, el Código Civil de 1852 dispuso que los hijos ilegítimos - nacidos fuera del matrimonio cuando los padres tenían impedimento para casarse- no tienen ningún derecho de suceder en los bienes del padre -artículo 891-y los hijos naturales - los nacidos fuera del matrimonio cuando los padres no tenían impedimento para casarse - reconocidos por el padre "heredan el quinto, habiendo hijos o descendientes legítimos" —artículo 892.3-. El Código de 1936, en su artículo 762 estableció: "Si hay hijos legítimos e ilegítimos, cada uno de estos últimos recibirá la mitad de lo que reciba cada legítimo". La Constitución de 1979, artículo 233, y la de 1993, artículo 6, prescriben que "todos los hijos tienen iguales derechos y deberes". En armonía con este marco constitucional, el Código vigente de 1984, en su artículo 818, dispone:

"Todos los hijos tienen iguales derechos sucesorios respecto de sus padres. Esta disposición comprende a los hijos matrimoniales, a los extramatrimoniales reconocidos voluntariamente o declarados por sentencia, respecto a la herencia del padre o de la madre y los parientes de éstos, y a los hijos adoptivos".

Como se aprecia, el Código de 1852 no le reconoce al hijo ilegítimo la aptitud para ser titular del derecho de suceder en los bienes de su padre -limitación de la capacidad de goce-; el Código de 1936 le reconoce el derecho de recibir la mitad de lo que reciba cada legítimo - limitación de la capacidad de goce-; y el Código de 1984 dispone que los hijos extramatrimoniales - nacidos fuera del matrimoniotienen iguales derechos sucesorios que los matrimoniales - se le reconoce a los extramatrimoniales, que los códigos anteriores llamaron ilegítimos, su plena capacidad de gozar de la herencia de su padre-.

Los individuos y los grupos de individuos, como realidades sociales, preexisten a la intervención del Derecho, están fuera del Derecho y antes que el Derecho, pero la subjetividad jurídica no se identifica con tales realidades, porque la subjetividad depende de la valoración que haga cada ordenamiento jurídico, de ahí que una cosa son los individuos y los grupos de individuos como realidades sociales y otra cosa son estos individuos y grupos como sujetos de Derecho. Una cosa es el ser humano como tal y otra su personalidad jurídica o subjetividad.

El ser humano, llámesele persona, individuo, hombre, agente, sujeto en cuanto tal -no todavía sujeto de Derecho-y los grupos de seres humanos constituyen un prius del ordenamiento jurídico - Derecho-; no porque existe el ordenamiento jurídico viene a existir el ser humano o los grupos de seres humanos, sino porque existen los seres humanos y los grupos de seres humanos viene a existir el ordenamiento jurídico.

En los Fundamentos del Proyecto de Código Civil argentino de 1998, se lee:

"Libro Segundo. De la parte general. Título I. De las personas humanas. 2. Se adopta la terminología personas humanas a lo largo de todo el Código. (...) la noción de persona 
proviene de la naturaleza; es persona todo ser humano, por el solo hecho de serlo; y la definición de la persona a partir de su capacidad de derecho confunde al sujeto con uno de sus atributos, amén de que da la falsa idea de que la personalidad del sujeto es concedida por el ordenamiento jurídico. La idea del Proyecto es por el contrario que la persona es un concepto anterior a la ley; el Derecho se hace para la persona que constituye su centro y su fin".

Esta argumentación se adapta al Código Civil y comercial argentino, por cuanto este establece que la "existencia de la persona humana comienza con la concepción" —artículo 19-. Pero esta prescripción del Derecho civil y comercial argentino no es aplicable a los Derechos positivos, desde el romano hasta la actualidad, que diferencian entre concebido y persona natural, verbigracia, nuestro Código dispone: Artículo 1. "La persona humana es sujeto de derecho desde su nacimiento", es decir, el concebido no es persona. El ser humano desde su concepción hasta su muerte es un prius de todo ordenamiento jurídico, pero no todo ser humano es persona, sino únicamente el que cumple con los requisitos establecidos por el Derecho positivo, como cuando este establece que es persona solamente el que nace vivo, aunque viva por breves instantes; el concebido no es persona.

Todo ser humano nacido vivo es persona natural, sea hombre o mujer, al que el Derecho le confiere personalidad jurídica para ser sujeto de relaciones jurídicas, que es la capacidad reconocida por el Derecho para ser sujeto de relaciones jurídicas, es decir, para ser titular de derechos y deberes, o sea centro de imputación de derechos y deberes jurídicos -obligaciones, cuando los deberes son de naturaleza patrimonial一.

En el mundo natural encontramos que todos los individuos, en cuanto tales, sin acepción de ninguna particularidad - biológica, psicológica, cultural, etc.-, son sustancialmente iguales, no son más o menos individuos, más o menos personas, sino simplemente personas, pero también encontramos que entre los individuos existen diferencias particulares que constituyen a cada individuo y las distingue de otros. Las características o cualidades que diferencian a una persona de otra constituyen la personalidad. Cada persona tiene su propia personalidad, entendida como el conjunto de características o cualidades - buenas o malas- que lo diferencian de las otras personas, no podemos decir que Adolfo Hitler y la Madre María Teresa de Calcuta tenían la misma personalidad o que Vladimiro Montesinos - el asesor del expresidente Fujimori-y Santa Rosa de Lima tienen idéntica personalidad. Del mismo modo, en el mundo jurídico la personalidad jurídica no es igual en todos los individuos, sino que ella depende de la valoración que de la realidad social haga el ordenamiento para conferirle a los individuos y grupos sociales subjetividad jurídica, es decir, la aptitud para asumir la calidad de sujetos de derechos.

Los romanos se orientaron por el principio hominum causa omne ius constitutum, o sea que el Derecho es constituido por los hombres en interés de los hombres, por tanto, en presencia del instituto de la esclavitud, no todos los hombres son sujetos de Derecho ${ }^{12}$.

Históricamente, decir que se es persona, para referirse a la especie humana: varón o mujer, no significa ser necesariamente sujeto de Derecho. En su acepción originaria persona significa "máscara", y son personas todas aquellas que tienen forma y apariencia humana, prescindiendo de la subjetividad jurídica.

En el Derecho moderno, la subjetividad jurídica es atribuida no solamente a las personas físicas sino también a colectividades de personas constituidas o no en personas jurídicas, a ma-

12. PASTORI, Franco. Op. Cit., pp. 165 y subsiguientes. En la parte histórica seguimos a este autor. 
sas patrimoniales privadas transitoriamente de titular, entre otros entes ${ }^{13}$.

La calificación de sujeto de Derecho es el presupuesto de la configuración de la relación jurídica, entendida como el vínculo entre sujetos a los cuales el ordenamiento atribuye derechos y los correlativos deberes -obligaciones, cuando los deberes son de naturaleza patrimonial-. La subjetividad jurídica es la abstracta aptitud para adquirir derechos y contraer obligaciones, mientras el efectivo conferimiento de tales derechos y obligaciones concierne a la titularidad jurídica: activa, con resguardo a los derechos, pasiva, con referencia a los deberes.

La personalidad jurídica expresa la condición o calificación jurídica del sujeto para que en cabeza de él se constituyan, modifiquen o extingan relaciones jurídicas. La personalidad jurídica no es un carácter del individuo en cuanto tal, sino que le es atribuida por una norma jurídica de organización, luego de valorar como socialmente útil el reconocimiento de la idoneidad del sujeto para ser destinatario de derechos y deberes.
La aptitud genérica para ser titular de derechos y deberes, se llama capacidad de goce, la misma que se identifica con la personalidad jurídica. Esa aptitud genérica se articula en específicas capacidades relativas a determinadas relaciones jurídicas, como la capacidad suceder, de adquirir el dominium, etc.

Todos los seres humanos somos iguales ante la ley, "nadie puede ser discriminado por motivos de origen, raza, sexo, idioma, religión, opinión, condición económica" - artículo 2.2 de la Constitución-, discapacidad ${ }^{14}$ o de cualquier otra índole. La ley debe ser aplicada por igual a todas las personas que se encuentren en la situación descrita en el supuesto de la norma. Sin embargo, no toda desigualdad constituye discriminación, no está proscrita toda diferencia de trato, no es discriminatoria cuando está justificada por razones objetivas y razonables, por ejemplo, no se podrá decir que no está justificado impedir que una persona que carece de las extremidades superiores pilote un avión, que un banco otorgue un crédito por una fuerte suma a un mendigo, que un presidente condenado por ladrón vuelva a ser presidente ${ }^{15}$.

13. Un claro ejemplo de esto lo constituye el artículo 6 de la Ley de Enjuiciamiento Civil española, Ley 1/2000, de 7 de enero que dispone: "Artículo 6. Capacidad para ser parte. 1. Podrán ser parte en los procesos ante los tribunales civiles: $1^{\circ}$ Las personas físicas. $2^{\circ}$ El concebido no nacido, para todos los efectos que le sean favorables. $3^{\circ}$ Las personas jurídicas. $4^{\circ}$ Las masas patrimoniales o los patrimonios separados que carezcan transitoriamente de titular o cuyo titular haya sido privado de sus facultades de disposición y administración. $5^{\circ}$ Las entidades sin personalidad jurídica a las que la ley reconozca capacidad para ser parte. $6^{\circ}$ El Ministerio Fiscal, respecto de los procesos en que, conforme a la ley, haya de intervenir como parte. $7^{\circ}$ Los grupos de consumidores o usuarios afectados por un hecho dañoso cuando los individuos que lo compongan estén determinados o sean fácilmente determinables. Para demandar en juicio será necesario que el grupo se constituya con la mayoría de los afectados. $8^{\circ}$ Las entidades habilitadas conforme a la normativa comunitaria europea para el ejercicio de la acción de cesación en defensa de los intereses colectivos y de los intereses difusos de los consumidores y usuarios. 2. Sin perjuicio de la responsabilidad que, conforme a la ley, pueda corresponder a los gestores o a los partícipes, podrán ser demandadas, en todo caso, las entidades que, no habiendo cumplido los requisitos legalmente establecidos para constituirse en personas jurídicas, estén formadas por una pluralidad de elementos personales y patrimoniales puestos al servicio de un fin determinado".

14. Convención sobre los Derechos de las Personas con discapacidad: Artículo 2. Por "discriminación por motivos de discapacidad" se entenderá cualquier distinción, exclusión o restricción por motivos de discapacidad que tenga el propósito o el efecto de obstaculizar o dejar sin efecto el reconocimiento, goce o ejercicio, en igualdad de condiciones, de todos los derechos humanos y libertades fundamentales en los ámbitos político, económico, social, cultural, civil o de otro tipo. Incluye todas las formas de discriminación, entre ellas, la denegación de ajustes razonables".

15. Sentencia del Tribunal Constitucional: Expediente 048- 2004-AA/TC: "El derecho a la igualdad presenta dos facetas: igualdad ante la ley e igualdad en la ley. La primera de ellas quiere decir que la norma deberá ser aplicable por igual a todos los que se encuentren en la situación descrita en el supuesto de la norma; mientras que la segunda implica que un 
El Derecho positivo no solamente confiere personalidad jurídica al ser humano sino también a colectivos o agrupaciones de personas, a los que en su calidad de sujetos de derecho les atribuye derechos y los correlativos deberes: personas jurídicas, que son tales cuando son inscritas en el registro respectivo, agrupaciones de personas no inscritas, a ciertos patrimonios autónomos - sociedad conyugal, patrimonios indivisos, etc.-. Se reconoce como sujeto de derecho a la persona jurídica independientemente de las teorías que se esgrimen para su justificación: ficción jurídica - Savigny-; teoría de la voluntad — von Gierke, Giorgio del Vecchio-; teoría del interés — von lhering-; de la institución - M. Hauriou-; teoría formalista -Kelsen-.

Se habla de personas naturales y jurídicas, pero en esencia ambas son jurídicas, ambas están referidas a normas jurídicas que las establecen. La persona es una creación de la ciencia del Derecho para facilitar la creación de la realidad jurídica - Kelsen-. Sin embargo, la distinción entre personas naturales y jurídicas se ha impuesto en el lenguaje jurídico.

Es el ordenamiento jurídico el que establece quienes son sus destinatarios ${ }^{16}, y$, en consecuencia, quienes pueden ser centro de imputación de derechos y deberes. No hay que perder de vista que no nos encontramos en el mundo de la naturaleza, del ser, regido por la ley de la causalidad, sino en el mundo de la libertad, del deber ser, en el que el Derecho lo puede todo con el fin de lograr una convivencia justa, pacífica, libre, en el que prime el interés común sobre el individual.

\section{CAPACIDAD JURÍDICA}

La capacidad es la aptitud atribuida o reconocida por el ordenamiento jurídico a los sujetos para ser titulares de derechos y deberes - capacidad de goce- y para el ejercicio de esos derechos y deberes - capacidad de ejercicio o de obrar-.

En el campo de la Administración pública y en el obrar de los órganos de gobierno de las personas jurídicas, a la capacidad de ejercicio lo encontramos con la denominación de competencia; en el Derecho penal se le llama imputabilidad.

\section{Concepto de capacidad de goce.}

La capacidad de goce llamada también - jurídica, de Derecho, pasiva o genérica- es la aptitud o idoneidad que tiene el sujeto para ser titular de derechos y deberes jurídicos. Dicho en otros términos, la capacidad jurídica es la aptitud que tiene el sujeto para ser titular de relaciones jurídicas, ya como sujeto activo - titular de derechos-, ya como sujeto pasivo titular de deberes-. Es intrínseca y meramente recepticia: no requiere de acto alguno de la persona, basta el hecho de su existencia, no es necesaria su aceptación. Todos los seres humanos nacen libres e iguales en los derechos proclamados por el ordenamiento jurídico ${ }^{17}$ y pueden gozar de ellos hasta su muerte. Ningún ser humano puede estar privado de su capacidad de goce. La Ley puede privar o limitar la capacidad de goce solamente respecto de determinados hechos o actos jurídicos; no existe una incapacidad de goce absoluta.

mismo órgano no puede modificar arbitrariamente el sentido de sus decisiones en casos sustancialmente iguales y que cuando el órgano en cuestión considere que debe apartarse de sus precedentes, tiene que ofrecer para ello una fundamentación suficiente y razonable (... ) Sin embargo, la igualdad, además de ser un derecho fundamental, también es un principio constitucional de la organización del Estado social y democrático de derecho y de la actuación de los poderes públicos. Como tal, comporta que no toda desigualdad constituye necesariamente una discriminación, pues no se proscribe todo tipo de diferencia de trato; la igualdad solamente será vulnerada cuando el trato desigual carezca de una justificación objetiva y razonable". De todo lo expuesto, la aplicación del test de igualdad estricto a este caso concreto permite concluir que la diferencia no es discriminatoria y, por lo tanto no vulnera el principio de igualdad (...)"

16. "El sujeto del derecho es aquel al que la ley destina la utilidad del derecho (el destinatario); la misión del derecho no es otra que la de garantizar esa utilidad": IHERING, Op. Cit., p. 178. 
La capacidad jurídica puede ser general, cuando es atribuida para la totalidad de los derechos subjetivos reconocidos a las personas por el ordenamiento jurídico, y especial, cuando se refiere a determinados derechos, verbigracia, la capacidad para hacer testamento, la capacidad para la adopción requiere que la edad del adoptante sea por lo menos igual a la suma de la mayoridad y la del hijo por adoptar - artículo 378.2 - la capacidad para contraer matrimonio entre una mujer y un hombre - nuestro ordenamiento jurídico, todavía no atribuye el derecho de contraer matrimonio entre personas del mismo sexo-. La capacidad jurídica general se adquiere por el nacimiento —artículo 1-; mientras que la capacidad jurídica especial se establece caso por caso.

El concebido, aún no nacido - nasciturus-, es sujeto de derecho para todo cuanto le favorece -artículo 1-. El Código sigue el principio romano que afirma: "conceptus pro iam nato habetur de eius conmodis agitur" —el concebido se tiene por nacido para todos los efectos que le sean favorables-. Por tanto, el concebido está protegido por el Derecho que le atribuye una cierta capacidad de goce. Tiene derecho a la vida, a su integridad psicofísica — la ley sanciona al aborto como delito-. La atribución de capacidad al concebido de derechos patrimoniales es condicional, como se advierte en el propio artículo 1, cuando dispone, "la atribución de derechos patrimoniales está condicionada a que nazca vivo". La capacidad de goce del concebido no es plena, sino parcial, limitada a lo que le sea favorable. En cada caso concreto se determinará si los derechos vinculados a obligaciones, cargas o sujeciones son o no favorables al concebido.

Se suele identificar capacidad de goce con subjetividad jurídica, entendida esta como la apti- tud que tienen los sujetos para ser titulares de derechos y deberes o de situaciones jurídicas subjetivas.

\section{El nacimiento como requisito para que la persona humana adquiera su plena capa- cidad de goce.}

La doctrina jurídica actual no discute sobre la distinción entre: las personas físicas o naturales, o sea los individuos humanos, y las personas jurídicas, que son entes diversos del hombre, como dos categorías de sujetos de Derecho. En ambos casos la calificación de sujeto de Derecho depende exclusivamente de la valoración realizada por el ordenamiento jurídico. Por ello, la terminología es impropia, dado que también las personas físicas son calificadas jurídicamente. Pero, hecha tal precisión, no hay motivo para cambiar un léxico tradicional.

A su vez, las personas jurídicas pueden consistir en una colectividad de personas reunidas para perseguir un objetivo común, colectividad que el ordenamiento considera de modo unitario y distinto de los singulares componentes, verbigracia, las asociaciones, las sociedades comerciales. Además, la calificación de persona jurídica como sujeto de Derecho puede ser conferida por el ordenamiento a la afectación de uno o más bienes de modo permanente para la realización de objetivos de carácter religioso, cultural, asistencial u otros de interés social; en este caso, se habla de fundaciones - artículo 99-.

El ordenamiento jurídico confiere la calificación de sujeto de Derecho en primer lugar a los individuos, como la categoría principal de los sujetos jurídicos, a los cuales alude con la expresión persona humana -artículo 1- para diferenciarla de la categoría de las personas jurídicas —artículo 76 y subsiguientes-.

17. Declaración Universal de Derechos Humanos: "Artículo 2. Toda persona tiene los derechos y libertades proclamados en esta Declaración, sin distinción alguna de raza, color, sexo, idioma, religión, opinión política o de cualquier otra índole, origen nacional o social, posición económica, nacimiento o cualquier otra condición. Además, no se hará distinción alguna fundada en la condición política, jurídica o internacional del país o territorio de cuya jurisdicción dependa una persona, tanto si se trata de un país independiente, como de un territorio bajo administración fiduciaria, no autónomo o sometido a cualquier otra limitación de soberanía". 
La condición necesaria, aunque no suficiente en el Derecho romano, para que el hombre pueda ser calificado como sujeto de Derecho es su existencia. Hecho, sin duda, natural, pero que el Derecho valora como una disciplina propia, por lo que la palabra existencia tiene un significado técnico-jurídico, que puede o no coincidir con su significado puramente natural. La existencia requiere de la verificación del nacimiento, que es la completa separación del feto del vientre materno: "partus enim antequam edatur mulieris portio est vel viscerum" -Digesto 2,5,4,1,1-, en cuanto, antes de tal separación, el feto, como parte del cuerpo de la mujer, está privado de autonomía jurídica propia.

Las fuentes romanas - Digesto 50,16,129- afirman: "qui mortui nascuntur neque nati neque procreati videntur", en cuanto que para la existencia el Derecho prevé como requisito que el individuo haya nacido vivo, o sea que haya tenido vida propia después de la separación del vientre materno. No se requiere que tenga también viabilidad, o sea la idoneidad para poder seguir viviendo extrauterinamente. Otro requisito exigido por el Derecho romano es la perfección del parto, que ocurre cuando el nacimiento se produce por lo menos seis meses después de la concepción; contrariamente se trataría de un aborto —Paulo 4,9,5 y 6; Digesto 1,5,12-, además se exige que el individuo tenga semejanza humana —Paulo 4,9,3 y 4; Digesto 1,5,14-.

El Derecho romano considera también al concebido como sujeto de Derecho, pero partiendo de la premisa que la subjetividad jurídica no puede subsistir separadamente del nacimiento. En efecto, las relaciones jurídicas de las que es titular el concebido se encuentran en estado de pendencia, o sea de incerteza sobre si nacerá o no con vida. Pero la pendencia no está privada de consecuencias jurídicas porque los derechos adquiridos por el sujeto con el nacimiento, son aquellos que tienen su origen -si bien todavía como meras expectativas - desde el tiempo de la concepción; por ello se ha previsto que un oficial privado, el curator ventris, tutele la expectativa del que está por nacer. El concebido, de acuerdo con la noción de ciudadano romano, nace libre y tiene el status de civis, aun cuando la madre al momento del nacimiento haya perdido la condición de mujer libre o de ciudadana.

Dentro de estos límites debe ser entendida la afirmación "qui in utero sunt in toto paene iure civili intelleguntur in resum natura esse" -Digesto 1,5,26- y la máxima "conceptus pro iam nato habetur", que parecen acercar la condición del concebido a la del que ha adquirido la calificación de sujeto como consecuencia del nacimiento. En realidad, la adquisición de la personalidad jurídica no puede prescindir del evento del nacimiento, más allá de las expectativas debidas al estado de pendencia que perdura durante la concepción. La adquisición de la personalidad jurídica se remonta al tiempo de la concepción para lo que le favorezca al concebido a condición de que nazca vivo.

La doctrina del Derecho romano pervive todavía, con algunas diferencias, en aquellas legislaciones que distinguen entre concebido y persona humana, como sucede con nuestro Código Civil. Para nuestro ordenamiento civil, el concebido es sujeto de derecho para todo cuanto le favorece, pero la atribución de derechos patrimoniales está sujeta a la condición resolutoria de que nazca vivo - artículo 1-. La fórmula utilizada por el Derecho peruano consiste en exigir que el concebido nazca vivo para que continúe siendo titular de sus derechos patrimoniales adquiridos antes de nacer, aun cuando haya vivido por breves instantes, sin exigirse ninguna otra circunstancia objetiva. En cambio, otras legislaciones contienen otras exigencias, como la viabilidad, que el nacido tenga vida independiente durante un período mínimo. Por ejemplo, el artículo 30 del Código Civil español, antes de su modificación en el año 2011, disponía: "Para los efectos civiles, solo se reputará nacido el feto que tuviese figura humana y viviere veinticuatro horas enteramente desprendido del seno materno"m8.

18. Este artículo fue modificado por Ley 20/2011 del 21.7.2011, en los siguientes términos: "Artículo 30. La personalidad se adquiere en el momento del nacimiento con vida, una vez producido el entero desprendimiento del seno materno". 
Conforme al artículo 1 del Código Civil, la capacidad de goce se adquiere plenamente con el nacimiento. El concebido tiene capacidad de goce, pero con la limitación de que la atribución de derechos patrimoniales está condicionada a que nazca vivo. O sea, nuestro Código distingue entre persona humana, que principia con el nacimiento, y vida humana que comienza con la concepción. En nuestra opinión, esta es una concepción que ya debe ser superada, porque la persona humana comienza con la concepción -intrauterina o extrauterina- y goza de capacidad jurídica hasta su muerte, capacidad que solamente puede ser limitada, excepcionalmente, para determinados hechos o actos jurídicos.

La concepción de un ser humano, el nacimiento del concebido y la constitución de una persona jurídica conlleva la consecuencia de que cada uno de estos entes es considerado un miembro más de la comunidad en la cual se inserta, en cuanto a que de inmediato es titular de derechos y deberes aun cuando no los conozca ni esté en condiciones de conocerlos o no pueda ejercitarlos personalmente. A partir de su existencia tienen personalidad jurídica, o sea tienen la capacidad de ser sujetos de relaciones jurídicas, esto es, el ordenamiento les reconoce la aptitud de ser titulares de derechos y deberes u obligaciones, pero no todos tienen la misma capacidad de goce. Así, las personas jurídicas no pueden ser titulares de los derechos personalísimos del ser humano, como el derecho a la vida, a la integridad física y psicológica, etc. La capacidad de goce de las personas jurídicas queda limitada, por la ley o por el acto de su constitución, a la finalidad para la cual han sido constituidas, verbigracia, una asociación no puede perseguir un fin lucrativo - artículo $80-$, el cual es propio de las sociedades mercantiles, cuya "capacidad de goce está determinada por su objeto social, esto es, que si, por ejemplo, se constituye para ser empresa bancaria puede realizar todas las operaciones y celebrar todos los actos jurídicos que le permitan las leyes que norman las actividades bancarias, pero no podrá, por ejemplo, explotar un yacimiento minero o desarrollar actividades propias de la industria manufacturera"m?.

El principio debe ser que toda persona humana es tal y tiene capacidad de goce desde su concepción -intrauterina o extrauterina- hasta su muerte. Sin embargo, este principio no es reconocido por todas las legislaciones, pues hay muchas que establecen que la existencia legal de la persona comienza con el nacimiento, privándole al concebido de plena capacidad jurídica, al disponer que los derechos que se le reconoce están sujetos a condición suspensiva de que nazca vivo - capacidad jurídica suspendida-. Así, por ejemplo, el Código de Andrés Bello que rige en Colombia dispone que:

"la existencia legal de toda persona principia al nacer, esto es, al separarse completamente de su madre. La criatura que muere en el vientre materno, o que perece antes de estar completamente separada de su madre, o que no haya sobrevivido a la separación un momento siquiera, se reputará no haber existido jamás" - artículo 90-; "los derechos que se diferirian a la criatura que está en el vientre materno, si hubiese nacido y viviese, estarán suspensos hasta que el nacimiento se efectúe. $Y$ si el nacimiento constituye un principio de existencia, entrará el recién nacido en el goce de dichos derechos, como si hubiese existido al tiempo en que se defirieron" - artículo 93-.

El Código Civil para el Distrito Federal de México establece que:

"la capacidad jurídica de las personas físicas se adquiere por el nacimiento y se pierde por la muerte; pero desde el momento en que un individuo es concebido, entra bajo la protección de la ley y se le tiene por nacido para los efectos declarados" en dicho Código - artículo 22-. 
El Código alemán -artículo 1- dispone que "la capacidad jurídica de la persona comienza con la consumación del nacimiento". El Código Civil italiano de 1942 -artículo 1- prescribe que "la capacidad jurídica se adquiere desde el momento del nacimiento. Los derechos que la ley reconoce a favor del concebido están subordinados al evento del nacimiento". Expresa Messineo ${ }^{20}$, que "antes del nacimiento, el sujeto es inexistente y no adquiere personalidad, ni derechos". Por ejemplo, si Tizio muere, en ese momento se abre la sucesión de su patrimonio a favor de sus herederos, entre los cuales está comprendido su hijo aún no nacido, pero a condición de que nazca vivo. Si nace vivo, el hijo adquiere los bienes hereditarios, como si ya hubiese nacido al momento en que Tizio, su padre, falleció; el hijo nacido después de la muerte de su padre, por una ficción de la ley, es considerado heredero desde el momento de la concepción, es decir, no solamente desde el momento en que su padre muere ni desde el momento en que él nace.

En nuestra opinión, si se pretende identificar vida humana con persona, se debe modificar el artículo 1 del Código Civil disponiendo:

"La existencia de la persona humana comienza con la concepción. Esta se inicia con la anidación del óvulo fecundado en el útero de la mujer. Los derechos y obligaciones del concebido quedan irrevocablemente adquiridos si nace con vida. Si nace nuerta se considera que la persona nunca existió. El nacimiento con vida se presume".

\section{Limitaciones a la capacidad de goce.}

Antes de su modificación por el Decreto Legislativo 1384, publicado el 4.9.2018 prescribía: "Artículo 3. Toda persona tiene el goce de los derechos civiles, salvo las excepciones expresamente establecidas por la ley".

Ahora el texto vigente, con la aludida modificación, dispone:
"Artículo 3. Capacidad jurídica. Toda persona tiene capacidad jurídica para el goce y ejercicio de sus derechos.

La capacidad de ejercicio solo puede ser restringida por ley. Las personas con discapacidad tienen capacidad de ejercicio en igualdad de condiciones en todos los aspectos de la vida."

Según esta norma, la capacidad de goce no se puede limitar, solo se puede restringir la capacidad de ejercicio.

En la doctrina, a la capacidad de "goce" también se denomina "jurídica", pero en esencia tanto la capacidad de goce como la de ejercicio son jurídicas, por cuanto es el Derecho positivo el que reconoce a toda persona la aptitud para ser titular de derechos y deberes jurídicos y para el ejercicio de los mismos, en ambos casos con las limitaciones establecidas por la ley. Desde esta perspectiva se justifica que el texto modificado del artículo 3 denomine "jurídica" tanto a la capacidad de goce como a la de ejercicio: "Toda persona tiene capacidad jurídica para el goce y ejercicio de sus derechos".

Sin embargo, no se puede dejar de mencionar que en la realidad social las expresiones capacidad de goce o jurídica y capacidad de ejercicio o de obrar son de admisión, conocimiento y aceptación general; las leyes se hacen para facilitar las relaciones sociales y no para satisfacer el ego del legislador. El Código de 1936, al que se debió hacer las modificaciones exigidas por la realidad social, fue sustituido por el vigente Código de 1984, al que se ha hecho ya una serie de modificaciones, muchas veces dos, tres veces al mismo artículo, sin un estudio serio de la institución jurídica, con el solo propósito de satisfacer el ego del "jurista", del "maestro del derecho", que propone la modificación, generando un ordenamiento jurídico sumamente contradictorio, que en ocasiones convierte a la mentira en verdad, cuyas conse-

20. MESSINEO, Francesco. Manual de Derecho civil y comercial. Tomo II. Op. Cit., p. 90. 
cuencias las sufre la población con la inseguridad jurídica en la que tiene que vivir. Sin duda, somos un país tercer mundista en extremo en materia jurídica.

El ordenamiento jurídico no solamente confiere capacidad de goce y capacidad de ejercicio a la persona humana y al concebido - ambos son vida humana-, sino también a ciertas entidades, agrupaciones o colectivos, a los que ha personificado por razones de índole diversa.

Según la norma del artículo 3, la capacidad de goce no puede ser limitada por la ley, porque sería como negar la propia existencia de la persona; solamente la capacidad de ejercicio puede ser restringida por la ley.

La afirmación en el sentido que la libertad de goce no puede ser limitada parte de quienes sostienen enfáticamente que la libertad del ser humano no puede ser limitada, como si cada persona tuviera el derecho de hacer cualquier cosa, incluso en el cuerpo de los demás ${ }^{21}$. Pero con una libertad ilimitada, con un poder soberano de cada individuo, no habría seguridad para nadie, la libertad se concentraría en el más fuerte que esclavizaría o sometería a servidumbre a los demás. Mientras cada individuo mantenga su derecho de hacer todo cuanto le agrade, las personas están condenadas a vivir en una situación de guerra permanente, cada individuo tiene derecho a todo y a defenderse así mismo por todos los medios, no pudiendo despojarse de ese derecho porque significaría ofrecerse a sí mismo como presa ${ }^{22}$. Para salir de este estado de libertad natural, ilimitada, los hombres limitaron su libertad mediante la constitución de la sociedad civil -más tarde el Estado- con una autoridad que, como su representante, haga o promueva lo que concierne a la paz y la seguridad comunes $^{23}$. La libertad sin límites no es sino la negación de la libertad. Solamente la libertad que permanece en la conciencia de la persona, que no se ha exteriorizado, es ilimitada, pero ella, por no haberse convertido en fenómeno social, no tiene ninguna trascendencia para el Derecho, este no se ocupa de ella; en cambio, la libertad exteriorizada necesariamente tiene que tener límites para que todos los seres humanos sean libres, por ello, como enseña la experiencia de vida desde las antiguas mores, pasando por los más grandes representantes de la filosofía y reconocida por las legislaciones de todo el mundo, es una verdad incontrastable que "mi libertad termina allí donde comienza la libertad de los demás" -Kant-; nadie tiene derecho a hacer aquello que le viene en gana, cuando quiere y como quiere, aun cuando con ello prive de su libertad a los demás, el Derecho no confiere derechos fundamentales ilimitados con el fin de que todos gocen de ellos, porque en caso contrario saldríamos de la civilización, dejaríamos de ser ciudadanos, para regresar al estado de naturaleza, a la ley del más fuerte. Ni siquiera el derecho fundamental a la vida es ilimitado: no se puede ignorar la pena de muerte en los casos que lo permite el ordenamiento jurídico ${ }^{24}$; cuando un

21. HOBBES, Thomas. Leviatán. Traducción de Manuel Sánchez Sarto. Segunda Edición. México: Fondo de Cultura Económica, 1994, p. 106.

22. Ibíd., p. 107.

23. Ibíd., p. 141: Para la seguridad común cada uno de los hombres someten su voluntad a un hombre o a una asamblea de hombres, por pacto constituido por cada individuo con los demás, como si cada uno dijera a todos: "autorizo y transfiero a este hombre o as amblea de hombres mi derecho de gobernarme a mí mismo, con la condición de que vosotros trasferiréis a él vuestro derecho, y autorizareis todos sus actos de la misma manera". El Estado en esencia se puede definir asi: "una persona de cuyos actos una gran multitud, por pactos mutuos, realizados entre sí, ha sido instituida por cada uno como autor, al objeto de que pueda utilizar la fortaleza y medios de todos, como lo juzgue oportuno para, para asegurar la paz y defensa común".

24. Constitución: "Artículo 140. La pena de muerte solo puede aplicarse por delito de traición a la patria en caso de guerra, y el de terrorismo, conforme a las leyes y a los tratados de los que el Perú es parte obligada". 
país se encuentra en estado de guerra se envía a los soldados al frente de batalla, no es para que en el enfrentamiento se pongan a rezar a la virgen, sino para que maten y los maten también. El ser humano no tiene derecho, verbigracia, a esclavizar, matar, estafar, secuestrar o a afectar en su integridad psíquica o física a sus congéneres; el hijo no tiene derecho a casarse con su madre; los que ejercen el poder político no tienen el derecho de robarle al Estado; nadie tiene el derecho de adquirir por prescripción los bienes de dominio público ${ }^{25}$; el Estado no tiene el derecho de promover el tráfico ilícito de drogas; el que no es peruano por nacimiento no tiene el derecho de ser Presidente del Perú. Se ejercen los derechos que se tienen no los que no se tienen. Solamente la ley puede privar o limitar la capacidad de goce de la persona humana.

La persona humana no solamente tiene el goce de sus derechos civiles, sino también de sus derechos políticos y de cualquier otra índole, que le reconoce el ordenamiento jurídico, con las limitaciones parciales establecidas por la ley, lo que es propio de todo ordenamiento jurídico.

En otros términos, la capacidad jurídica pertenece a todo ser humano, solo excepcionalmente y por disposición expresa de la ley, la persona puede ser privada o limitada en el goce de determinados derechos civiles o de otra índole. Por eso, la incapacidad de goce no puede ser sino parcial, no puede existir una incapacidad de goce absoluta, plena, por cuanto no se puede privar al ser humano sino del goce de alguno o algunos derechos determinados, jamás de todos. Superados los estadios históricos de la esclavitud y la pena de muerte $\mathrm{civi}^{26}$ - que determinaron la existencia de seres humanos sin derechos - toda persona humana tiene derechos y deberes.

No existe, pues, una incapacidad absoluta de goce, puesto que ninguna persona puede estar privada de todos los derechos, como sucedía con la esclavitud y la pena de muerte civil seres humanos sin personalidad-, hoy, para bien de la humanidad, desaparecidas. Solamente puede existir una incapacidad parcial relativa - de goce expresamente establecida por ley en defensa de intereses superiores, de la moral, del orden público y también en protección de intereses particulares. La privación o limitación de la capacidad goce respecto de ciertos derechos se presenta como una capitis diminutio relativa debido a que no se pueden establecer incapacidades generales de goce, es decir, la incapacidad de goce impide ser titular de ciertos derechos subjetivos específicos, verbigracia, el concebido no tiene una plena capacidad de goce, el Presidente de la República y otros altos dignatarios estatales no tiene el derecho de adquirir los bienes nacionales ${ }^{27}$. La regla es la capacidad de goce y la excepción, la incapacidad parcial o relativa de goce. El artículo 3 del Código dispone que la capacidad de goce no se puede restringir, pero numerosas normas del mismo Código, como cualquier otro ordenamiento jurídico, privan o limitan la capacidad de goce de la persona humana respecto de ciertos actos o hechos jurídicos, verbigracia, el artículo 29 del Código Penal establece que la pena privativa de la libertad puede ser temporal o de cadena perpetua; en el primer caso

25. Constitución: "Artículo 73. Los bienes de dominio público son inalienables e imprescriptibles."

26. La muerte civil de las legislaciones antiguas perduró hasta mediados del siglo pasado. Los condenados por delitos graves a deportación eran reputados civilmente muertos. En el Derecho germánico, el juez, al aplicar esta pena, pronunciaba estas palabras: "Tu quedarás fuera del derecho. Viuda es tu mujer; sin padre tus hijos. Tu cuerpo y tus carnes son consagrados a las fieras de los bosques, a los pájaros del aire, a los peces de las aguas. Los cuatro caminos del mundo se abren ante ti para que vayas errante por ellos; donde todos tienen paz, tú no la tendrás." —BORDA. Manual de Derecho civil, Parte General. Op. Cit., p. 154-.

27. Código Civil: "Artículo 1366. No pueden adquirir derechos reales por contrato, legado o subasta pública, directa o indirectamente o por persona interpuesta: 1. El Presidente y los Vicepresidentes de la República, los senadores y diputados, los Ministros de Estado y funcionarios de la misma jerarquía, los bienes nacionales". 
tendrá una duración mínima de dos días y una máxima de 35 años.

En todos los casos en que la ley establece que una persona no puede ejercitar un determinado derecho, por sí mismo ni mediante representante, está privándole del goce de ese derecho; no puede ser titular de ese derecho ni de los deberes jurídicos correlativos a él. Las privaciones o limitaciones de la capacidad de goce están expresamente establecidas por ley, al margen de que el artículo 3 disponga que no se puede restringir la capacidad de goce. El que por ley está privado de ser titular de ciertos derechos subjetivos, no los puede ejercitar directa ni indirectamente porque no se puede ejercitar un derecho que no se tiene. Por ejemplo, los abogados no pueden adquirir, mediante contrato, legado o subasta pública, directa o indirectamente o por persona interpuesta, los bienes que son objeto de un juicio en que intervengan o hayan intervenido por razón de su profesión, hasta después de un año de concluido el proceso en todas sus instancias -artículo 1366.6-. El abogado tiene el goce de todos sus derechos civiles, entre los cuales se cuenta el de adquirir cualquier clase de bienes, con excepción de los que son objeto del proceso judicial en el cual ha intervenido como defensor de una de las partes. El abogado no puede adquirir estos bienes simplemente porque no tiene capacidad de goce para ello, ya que si la incapacidad fuera simplemente de ejercicio los podría adquirir mediante representante o por interpósita persona. Esta privación relativa de la capacidad jurídica del abogado por el plazo indicado tiene un fundamento moral, persigue evitar que incurra en abusos en el ejercicio de su noble profesión. Con fines de claridad citemos otros ejemplos: no tienen derecho a ser tutores de un menor: sus enemigos, los que fueron destituidos de la patria potestad, los que fueron removidos de otra tutela - artículo 515-; los tutores no tienen derecho para comprar los bienes del menor, para adquirir derechos o acciones contra el menor, para disponer los bienes del menor a título gratuito - artículo 538-; dentro de los cincuenta kilómetros de las fronteras, los extranjeros no tienen derecho para adquirir, por título alguno, minas, tierras, bosques, aguas, combustibles ni fuentes de energía -artículo 71 de la Constitución-; los que sufren pena privativa de la libertad por los delitos que han cometido no tienen derecho de transitar libremente dentro y fuera del país, así es en todo el mundo.

Muchas veces, las causas de capacidad de ejercicio restringida -incapacidad de ejercicio-, como la edad, enfermedad, condena penal, etc., pueden extender o restringir la capacidad de goce. Así, el menor no goza del derecho de otorgar testamento, salvo que siendo mayor de 14 años haya contraído matrimonio -artículo $687.1 \ldots 28$; los que adolecen de enfermedad crónica, contagiosa y transmisible por herencia no pueden contraer matrimonio - artículo 241.2-; están impedidos de ser tutores los que están sujetos a curatela —artículo 515-; el que sufre pena de prisión no puede circular libremente dentro y fuera del país. Estas personas no son titulares de los derechos subjetivos de testar, de contraer matrimonio, de ser representante legal de otra persona, de la libertad de tránsito, esto es, no tienen capacidad goce para realizar estos actos jurídicos.

28. El texto original del artículo 46 estableció que la incapacidad de las personas mayores de 16 años cesa por matrimonio. El Decreto Legislativo 1377, publicado el 24 de agosto de 2018, modificó el artículo 46, manteniendo el texto original del artículo 46 en cuanto establece que la incapacidad de las personas mayores de 16 años cesa por matrimonio. Solamente días después, el Decreto Legislativo 1384, publicado el 4 de setiembre 2018, modificó el artículo 42, disponiendo que los mayores de 14 años que han contraído matrimonio tienen "plena capacidad de ejercicio", pero no modifica el artículo 46, que establece que cesa la incapacidad por matrimonio de los que cumplen 16 años, ni el artículo 687.1 que dispone que los menores de 16 años no pueden otorgar testamento. Esto es lo que hacen nuestros "grandes juristas", sin que nadie les pueda poner freno. Hay que entender —aplicando la derogación tácita regulada por el artículo I del Título Preliminar- que los artículos 46 y 687.1 han sido modificados en el sentido que los mayores de 14 años y menores de 18 que han contraído matrimonio tienen plena capacidad de ejercicio, por tanto, pueden otorgar testamento. 
El Derecho regula solamente conducta humana social posible, dentro de este ámbito todo es posible para el Derecho, siempre que se persiga una finalidad lícita, salvo, como alguien ha dicho, el convertir a un hombre en mujer - aunque ahora ya se puede-; por tanto, es posible restringir por razones superiores que persigan no la negación sino la afirmación de la personalidad jurídica del ser humanola capacidad de goce de las personas, lo que implica limitar la libertad de las personas, lo que es normal en Derecho, lo anormal es una libertad ilimitada que no es otra cosa que la negación de la propia libertad, para dar paso a la ley del más fuerte, convirtiendo al hombre en lobo del hombre.

Por razones de organización social, el Derecho positivo reconoce o atribuye al sujeto derechos subjetivos dentro de ciertos límites. El sujeto no puede gozar de sus derechos excediendo esos límites. No existen derechos ilimitados, ni siquiera es ilimitado el derecho fundamental a la vida, del cual se derivan los otros, como sucede con la pena de muerte o cuando los jóvenes son enviados al frente de batalla en caso de guerra. No hay derechos fundamentales ilimitados, no hay libertad ilimitada del ser humano, por ejemplo, soy libre de contratar siempre que no contravenga las normas imperativas, el orden público, las buenas costumbres; soy libre de contraer matrimonio siempre que no sea casado; no soy libre de cometer delitos. Desde esta perspectiva, la capacidad de goce sufre limitaciones establecidas por ley.

\section{Doctrina que considera que no es posible que el derecho pueda limitar la capaci-} dad de goce. Crítica.

Como sabemos, la capacidad de goce es la aptitud genérica del sujeto de Derecho ${ }^{29}$ para ser titular de derechos y deberes, en la cual se articulan las aptitudes específicas relativas a determinados derechos como la capacidad de suceder, de testar, de contratar, etc. La capacidad de goce opera dentro de los límites establecidos por el ordenamiento jurídico. Por tanto, no se puede sostener que la capacidad de goce no se puede limitar por el Derecho, dado que ello sería como sostener que existe derecho sin ley - derecho sin Derecho-, sin norma jurídica, o afirmar que se puede ejercer un derecho que no se tiene porque la capacidad de ejercicio presupone la capacidad de goce, la cual no es afectada por la limitación de la capacidad de ejercicio. Solo se ejerce un derecho que se tiene o que razonablemente se cree que se tiene; los seres humanos solamente establecen relaciones jurídicas con otros seres humanos que tienen derechos y deberes, porque es una relación de persona a persona, no puede ser una relación jurídica con seres humanos sin personalidad -los esclavos-o con seres que solo tienen derechos sin ningún deber -Dios- ${ }^{30}$. Así, usamos, disfrutamos, disponemos y reivindicamos el bien que es de nuestra propiedad - artículo 923- o cuya propiedad, razonablemente, nos auto-atribuimos, estando todas las demás personas en el deber de respetar nuestra propiedad; el acreedor puede ejercer el derecho de su deudor - el derecho que realmente tiene o que, razonablemente, cree que tiene su deudor, y no una mera aptitud subjetiva de este-cuando este no lo ejerce y con ello va a perjudicar la recuperación del crédito - acción oblicua o subrogatoria: artículo 1219.4-.

Ningún ser humano puede ser privado de todos sus derechos, pero, por necesidad de una coexistencia social civil pacífica, el ordenamiento jurídico lo priva de determinados derechos o los limita, de manera que no existen personas privadas totalmente de su capacidad de goce, pero si parcialmente; no hacerlo por estimar que la libertad de los seres humanos no puede ser limitada, sería condenarlos a vivir en un es-

29. Con la palabra Derecho escrita con " $\mathrm{D}$ " mayúscula nos referimos al Derecho positivo, y con la palabra derecho escrita con "d" minúscula indicamos al derecho subjetivo.

30. KANT. Principios metafísicos del Derecho. Buenos Aires: Editorial Americalee, 1943, p. 59. 
tado de guerra permanente ${ }^{31}$. No obstante, un sector de la doctrina, entre ellos Busnelli ${ }^{32}$, considera que no se puede establecer limitaciones a la capacidad jurídica, debido a que esta:

\begin{abstract}
"no puede operar como un instrumento de discriminación, porque representa el aspecto estático y puro del sujeto, la abstracta posibilidad. Ello corresponde a la capacidad de ejercicio, la cual expresa, en el ámbito de la concreta realización de los fenómenos jurídicos, el aspecto dinámico e impuro de la condición del sujeto".
\end{abstract}

Fernández Sessarego ${ }^{33}$, citando a Galgano, Larenz y Bianca, sostiene que la capacidad genérica o de goce o jurídica es la pura aptitud, la mera potencialidad, que tiene todo ser humano de gozar de los derechos inherentes a su naturaleza. Libertad y capacidad de goce son elementos indisolubles, no se comprende la libertad sin la capacidad, que le es inherente, de realizarse en el mundo fenoménico. La libertad subjetiva y su capacidad inherente, puede o no fenomenalizarse. Tanto la libertad subjetiva y la libertad objetiva como la capacidad de goce y la capacidad de ejercicio, son cada cual una unidad que se nos muestra en dos momentos del devenir existencial del ser humano. La libertad ontológica y la capacidad de goce, por pertenecer al mundo interior del ser humano, de suyo incomunicable, son inmunes al Derecho. En cambio, la capacidad de ejercicio, que permite la manifestación fenoménica de la libertad, sí es posible limitarla, restringirla o suprimirla por el ordenamiento jurídico. La expresión capacidad de goce es equivalente a la de subjetividad jurídica o a la de personalidad jurídica - Galgano- La persona está dotada de capacidad jurídica "para ser sujeto de relaciones jurídicas y, por ello, titular de derechos y destinatario de deberes jurídicos", la capacidad jurídica "corresponde al individuo porque, conforme a su naturaleza, es persona en sentido ético" - Larenz-. La capacidad de ejercicio se refiere a la idoneidad del sujeto para desplegar directamente su propia autonomía negocial y procesal; la falta o limitación de la capacidad de ejercicio no incide sobre la capacidad jurídica en cuanto el sujeto permanece siempre idóneo a ser titular de relaciones jurídicas; de lo que carece el incapaz de ejercicio es de la idoneidad para realizar directa y autónomamente su propia esfera personal y patrimonial, necesitando un representante - Bianca-.

Por estas consideraciones, Fernández Sessarego propuso la modificación del artículo 3 del Código Civil peruano en los términos siguientes: "Artículo 3. Todo ser humano tiene el goce de los derechos civiles, salvo las excepciones a su ejercicio expresamente establecidas por ley".

Refutando esta doctrina, comencemos por precisar que, paradójicamente, el ser humano es, al mismo tiempo, esencialmente individuo

31. Los autores franceses Ripert y Boulanger escriben: "Se admitía antiguamente a título de pena, que ciertos condenados podían ser privados de todos sus derechos, y se daba a esta pena el nombre de muerte civil". Fue definitivamente suprimida por la ley del 31 de mayo de 1854. Esto no era, por otra parte, sino una ficción. No se puede suprimir absolutamente todos los derechos de una persona: sería hacerle imposible la vida. Pero los efectos de la muerte civil no eran por esto menos rigurosos, y hasta inmorales (disolución del matrimonio, apertura de la sucesión). La muerte civil fue reemplazada por una doble incapacidad de disponer y de recibir a título gratuito." RIPERT, Georges y BOULANGER, Jean. Tratado de Derecho civil según el tratado de Planiol. Traducción de Delia García Daireaux. Tomo I. Parte general. El Derecho - Insituciones civiles. Buenos Aires: La Ley, 1956, p. 311.

32. Citado por ESPINOZA ESPINOZA, Juan. La tutela jurídica de los sujetos débiles. Tesis (Magíster), Universidad Nacional Mayor de San Marcos, Lima, 1997, p. 11.

33. FERNÁNDEZ SESSAREGO, Carlos. "La capacidad de goce: ¿es posible su restricción legal?". En: Cáthedra, Revista de los Estudiantes de Derecho de la Universidad Nacional Mayor de San Marcos, Año III, No 5. Lima: 1999, p. 21 y subsiguientes.; GALGANO, Francesco. Diritto civile e commerciale. Volumen I. Padua: Cedam, 1990, p. 128; LARENZ, Karl. Derecho civil, Parte general. Madrid: Editorial Revista de Derecho Privado, 1978, p. 103; BIANCA, Massimo C. Diritto civile. Tomo I. Milán: Giuffrè, 1978, p. 193. 
-y como tal inmutable, inconfundible, insustituible e irrepetible; no existen dos seres humanos iguales en el mundo-y esencialmente sociedad - el ser humano no puede ser sin la sociedad; sin ella devendría en un animal irracional más-. De otra parte, el ser humano es libre, no hay acto humano sin libertad, pero "Ia libertad no es algo congénito en el hombre, sino algo que el hombre tiene que conseguir luchando incesantemente y resistiendo los flujos exteriores y sus propias inclinaciones"134, la historia de la humanidad es una historia de incesante lucha del ser humano por conseguir un mayor ámbito de libertad, verdad irrefutable, no se puede borrar la historia de la humanidad con una pura idealidad. Por eso se ha dicho que la historia es el estudio y comprensión de la libertad del hombre, el análisis de la acción libre del hombre, de los esfuerzos por la ampliación del marco en que el hombre puede vivir en libertad, los seres humanos fueron privados de sus derechos por ser de tal o cual raza, color, religión o por otras consideraciones, no siempre tuvieron el derecho de trabajar ocho horas sino de sol a sol, las mujeres no siempre tuvieron el derecho de elegir y ser elegidas para un cargo público, los campesinos del norte del Perú que se enganchaban para trabajar en las haciendas no tenían los mismos derechos que los hacendados, ni siquiera su vida estaba garantizada; la pura "abstracta potencialidad" de ser titular de un derecho no es derecho en ningún sentido, porque el Derecho solamente regula vida humana social de acuerdo a ciertos valores, en lugar y espacio determinados, los demás es cuento y puede servir solamente para justificar la explotación del hombre por el hombre, cosa que el Derecho trata de impedir, a veces lo logra otras, no; el individuo, de acuerdo a su naturaleza, es persona porque tiene derechos, pero limitados para que los tengan todos los individuos. No es posible dejar de reconocer que el derecho de libertad encuentra su límite en el derecho de libertad de los demás y en los deberes que el Derecho impone en beneficio de la existencia de una comunidad civil erigida sobre la idea del Derecho. La convivencia y el orden son imposibles entre individuos radicalmente libres, eso era posible cuando los individuos vivan en estado de naturaleza, sometidos a la ley natural de la fuerza bruta, pero no es posible en un estado de convivencia civil - status civilis-, en el que todos, gobernantes y gobernados, están sometidos a la ley civil, a ley de la fuerza institucionalizada.

El ser humano es incomunicable $y$, a la vez, comunicable, por naturaleza, o sea tiene un ámbito de incomunicabilidad —su mundo interno-y otro comunicable - no puede existir como ser humano sino en una permanente comunicación con los demás seres humanosEl concepto de libertad, como dice Paredes ${ }^{35}$, parafraseando a Lord Acton, depende de que se conciba al hombre como individuo, o como parte de un colectivo, o como persona.

El individualismo, que triunfó e implantó el liberalismo en el siglo XIX, considera al hombre-individuo como un ser radicalmente autónomo e independiente que se da sus propias leyes sin recurrir a instancias superiores. El hombre es la libertad y no es que tenga libertad. El hombre-individuo en su origen no es nada, niega la creación divina, no recibe de nadie su naturaleza sino que la realiza en una serie de actos libres, sin que se le imponga o se imponga a sí mismo ninguna responsabilidad o ligazón porque ello implicaría una disminución de su ser hombre.

Para el colectivismo, de mediados del siglo XIX, la convivencia ordenada es imposible entre individuos radicalmente libres. El individuo es solo una parte del todo. El hombre-colectivo, también, en su origen no es nada, niega la creación divina, realiza su naturaleza en el conjunto de obligaciones que debe asumir, y en la satisfacción de las necesidades naturales -derivadas del puesto que ocupa en el pro-

34. LARENZ, Karl. Derecho justo. Fundamentos de ética jurídica. Op. Cit., p. 61.

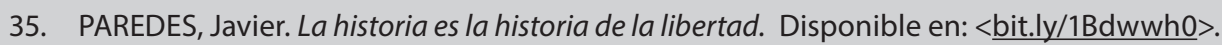


ceso productivo, o vinculadas a su raza, o sentadas instintivamente por la colectividad-y de las impuestas por la norma, a las que debe sujetarse para llegar a ser dentro del colectivo y permitir que el colectivo sea. La persona es un objeto del interés colectivo - la clase, la nación, la raza, el partido, el Estado-.

Para la concepción del hombre como persona, esta es un ámbito de incomunicabilidad -es ella y no otra-, y, a la vez, obligadamente comunicable - se es persona en la trascendencia, en el salir de sí-. El hombre como persona entiende que la naturaleza de que dispone no se da a sí mismo sino que es recibida; colabora en la producción de la naturaleza de otro, pero no crea la naturaleza propia ni la ajena. La identidad en la naturaleza de los distintos hombres permite deducir un creador común: Dios y una ordenación básica para todos: ley, norma, pauta, etc. El hombre no es la libertad sino tiene libertad; su esencia, su naturaleza no es la libertad. La libertad que tiene la persona no es ni omnímoda ni radical, por lo que puede realizar actos con los cuales queda ligada y obligada en virtud de la responsabilidad. La persona se guía por su conciencia, es decir, su capacidad de conocer y poner en práctica lo común a todos los hombres desde su individualidad. Sus derechos fundamentales emanan de su naturaleza, sin que haya autoridad que se los conceda por cuanto ya los posee, cosa distinta es que dicha autoridad se los reconozca y proteja.

La libertad subjetiva, no fenomenalizada, no puede ser regulada por el Derecho, por cuanto ello significaría una regulación de lo imposible, valorando a los sueños, pensamientos, sentimientos y a todo elemento del mundo natural psicológico como valioso o disvalioso, justo o injusto, lícito o ilícito; la libertad psicológica, no objetivada, nunca puede ser conformada con la libertad de los demás, no es materia de regulación jurídica. El Derecho no regula conducta humana imposible sino solo conducta posible, por lo que es erróneo denominar capacidad jurídica a la pura aptitud natural de las mujeres y hombres de gozar internamente de sus derechos subjetivos auténticos o imaginarios. La libertad subjetiva solamente puede ser limitada por la persona que la vive, determinada por factores internos o externos - morales, religiosos, económicos, jurídicos-. El Derecho regula la vida colectiva de los individuos fijando los límites de su libertad, estableciendo qué es lo que deben hacer -impone una determinada conducta-, o qué es lo que no deben hacer - prohíbe ciertas conductas indeseables para la comunidad-, o qué les está permitido hacer - tolera ciertos comportamientos y los protege en caso que sean obstaculizados-; en suma, el Derecho es un esquema de conducta debida que el que no lo cumple, se expone a sufrir las consecuencias jurídicas. El individuo por convicción o por temor a sufrir las consecuencias negativas establecidas por el Derecho puede abstenerse en su fuero interno de tomar decisiones que de ser exteriorizadas serían negativas para la sociedad. Supongamos, por ejemplo, que se da una ley que establece que "el robo no está penado", a partir de ese momento los ladrones sin ningún temor tomarían la decisión de robar y las personas honradas no tomarían la decisión de dar un paso hacia afuera de sus casas sin antes tomar las medidas necesarias para poder defenderse de los ladrones, o sea como consecuencia de esta norma los ladrones ampliarían su libertad subjetiva, mientras las personas honradas la limitarían, y viviríamos en un estado de guerra permanente, en el que la fuerza natural, no la institucionalizada, sería la que determina cuales individuos tienen libertada y cales, no.

En cambio, la libertad objetiva, -comunicada, fenomenalizada, cristalizada: llámenla como deseen- sí es regulada por el Derecho, ya que al ser exteriorizada y, por consiguiente, conocida por los demás, sí puede ser limitada jurídicamente por la autoridad en aras de una convivencia ordenada y pacífica. Una libertad sin límites, sin ley que la regule, no puede ser, porque no hay sociedad que no esté regida por normas jurídicas por rudimentarias que estas sean - ubi societas ibi ius-. Sin ley no hay libertad, salvo la libertad natural del más fuerte.

La libertad y capacidad ontológicas no fenomenalizadas, pertenecientes a la naturaleza psicológica del ser humano son inmunes al Derecho. La libertad y capacidad subjetivas fenomenali- 
zadas se denominan conducta humana social. El Derecho no regula conducta humana individual, sino solamente conducta humana social, es decir, la conducta de un sujeto que interfiere con la conducta de otro sujeto, y no toda conducta social sino solamente aquella que es posible de producir un conflicto de intereses o de generar una incertidumbre, o sea la conducta intersubjetiva que tiene relevancia para que la convivencia se desarrolle con orden, seguridad, paz, libertad y justicia. La personalidad jurídica o subjetividad jurídica o capacidad goce es la aptitud reconocida o atribuida por el ordenamiento jurídico a la persona para ser titular de derechos - titularidad activa- y deberes - titularidad pasiva-. La capacidad de goce objetivada es el objeto de la capacidad de ejercicio, se ejercita un derecho que se tiene no un derecho que no se tiene.

La teoría que sostiene que no es posible limitar la capacidad de goce, identifica al ser humano - como realidad preexistente al Derecho-, con la personalidad jurídica o subjetividad jurídica o capacidad jurídica o de goce - aptitud para ser sujeto de relaciones jurídicas-. Sin embargo, han escrito en el artículo 1 del Código Civil estableciendo que el concebido - ser humano- no es persona. Los seres humanos, personas o no personas, individuos o grupos sociales, constituyen una realidad preexistente a la intervención del Derecho, pero la subjetividad jurídica no se identifica necesariamente con dicha realidad. La capacidad jurídica o personalidad jurídica es reconocida o atribuida al hombre por el Derecho ${ }^{36}$. La subjetividad jurídica depende de la valoración que de la realidad haga el ordenamiento jurídico, valoración que no es la misma en todos los sistemas jurídicos. Estados con ordenamientos jurídicos de muy distinto signo y con concepciones del hombre sustancialmente diferentes determinan -dice González ${ }^{37}$ - que:

"se llegue a soluciones radicalmente contrarias sobre temas fundamentales tan de nuestros días como la admisibilidad de ciertas formas de procreación y manipulación genéticas, el aborto, la disponibilidad de órganos humanos, los experimentos médicos con personas y la eutanasia".

Así, por ejemplo, bajo ciertas condiciones, algunos ordenamientos jurídicos confieren a las personas el derecho de abortar, otros no; algunos reconocen el derecho de contraer matrimonio entre personas del mismo sexo, otros niegan ese derecho.

La subjetividad jurídica es la aptitud que tiene un ente para ser sujeto de relaciones jurídicas. El presupuesto de una relación jurídica es un hecho concreto de la vida real - ejemplo: Ticio causa un daño a Cayo; María contrae matrimonio con Juan-. Tal hecho constituye el substrato de la relación jurídica, pero no es la relación jurídica misma, sino que es una simple relación social, una pura relación de hecho. La relación jurídica es creada por el ordenamiento jurídico sobre la base de la relación social, a la cual — previa valoración no solo del comportamiento de las personas sino también de su aptitud para atribuirles derechos o deberes - vincula determinados efectos jurídicos consistentes en derechos

36. Larenz dice: "Desde el punto de vista zoológico, el hombre se puede definir como un ser viviente que presenta una serie de notas distintivas, que en parte tiene en común con los géneros de animales próximos a él, mientras se distingue de ellos por algunas otras. Así se consigue un 'concepto abstracto'. Si, en cambio, se entiende al hombre 'concretamente', lo que, sin embargo, no quiere decir un determinado hombre particular sino el tipo de hombre en la plenitud de todas sus posibilidades, entonces se le ve al propio tiempo como un ser corporal, anímico y espiritual, que se realiza de modo diverso en estas tres dimensiones y que se abre a nuevas posibilidades. El concepto concreto de hombre, así entendido, es el que se tiene en cuenta cuando atribuimos al hombre como tal un valor especial, una dignidad y, con respecto a su posición en el Derecho, determinadas capacidades, como la capacidad jurídica, la capacidad de acción y de responsabilidad. Con un concepto solo zoológico de hombre no se hubiera logrado nada aquí" —LARENZ, Karl. Metodología de la ciencia del Derecho. Traducción de Marcelino Rodríguez Molinero. Barcelona: Ariel, 1994, p. 448—. 
y los correspondientes deberes $\mathrm{u}$ obligaciones. En suma, la relación jurídica es el conjunto de efectos jurídicos consistentes en derechos y los correspondientes deberes $u$ obligaciones que el ordenamiento jurídico reconoce o atribuye a hechos o situaciones de la vida real.

La libertad subjetiva - y su capacidad subjetiva inherente- por permanecer en las profundidades de la conciencia, de suyo incomunicable, es inmune al Derecho, pero esa libertad y su inherente capacidad en su aspecto externo, fenomenalizado, de suyo comunicable, es necesariamente regulado, limitado ${ }^{38}$, por el Derecho para hacer posible la coexistencia de los seres humanos con orden, paz, seguridad libertad y justicia. A diferencia del ser humano en estado de naturaleza que goza de una absoluta libertad y de su inherente capacidad de goce, en la sociedad civil no puede existir un ser humano dotado de absoluta libertad y capacidad de goce, puesto que ello significaría la supresión de la libertad y capacidad de goce de los demás sujetos. El ser humano desenvuelve su personalidad dentro de los límites trazados por el ordenamiento jurídico ${ }^{39}$.

No existen derechos ilimitados, todo derecho, por más fundamental e inviolable que sea, tiene sus límites establecidos de acuerdo con las valoraciones que haga cada ordenamiento jurídico. Por ejemplo, el Tribunal Constitucional español, en su sentencia del 11 de abril de 1985, invoca la dignidad personal de la mujer para justificar el aborto cuando el embarazo es consecuencia de la violación:
"La gestación ha tenido su origen en la comisión de un acto no solo contrario a la voluntad de la mujer, sino realizado venciendo su resistencia por la violencia, lesionando en grado máximo su dignidad personal y el libre desarrollo de su personalidad, y vulnerando gravemente el derecho de la mujer a su integridad física y moral, al honor, a la propia imagen y a la intimidad personal(...) Obligarla a soportar las consecuencias de un acto de tal naturaleza es manifiestamente inexigible: la dignidad de la mujer excluye que pueda considerársela como mero instrumento, y el consentimiento necesario para asumir cualquier compromiso u obligación cobra especial relieve en este caso ante un hecho de tanta trascendencia como el de dar vida a un nuevo ser, vida que afectará profundamente a la suya en todos los sentidos ${ }^{140}$.

Nadie puede ser titular de una libertad sexual ilimitada, radical, porque ello significaría suprimir la dignidad y libertad sexual de los demás.

Solamente la libertad no cristalizada existente en la conciencia del ser humano, regulada por normas morales, es ilimitada. No hay que confundir la regulación de la moral, individual, social o religiosa, por normas incoercibles en este mundo, con la regulación de la vida social posible del ser humano con normas coercibles en este mundo, vida que se desarrolla necesariamente con limitaciones y privaciones de la libertad, para garantizar la libertad de todos. La regulación jurídica con mentiras puede resultar fatal para los derechos y

38. Legaz, dice: "Por necesidad ontológica, la negación de la personalidad jurídica a la persona humana no puede ser más que una excepción, que, además, tropezará con un mínimum infranqueable de subjetividad jurídica, que demostrará que el problema de la esclavitud, y en general el de las restricciones de la personalidad, no es tal problema de personalidad, sino de libertad" — LEGAZ Y LACAMBRA, Luis. "La noción jurídica de la persona humana y los derechos del hombre". En: Revista de Estudios Políticos No 55, Vol. XXXV. Madrid: 1951, p. 20-.

39. Larenz expresa: "El hombre como persona, en sentido ético, tiene una 'dignidad', es capaz de y está llamado a desenvolver su personalidad con responsabilidad ante sí y frente a otros y a realizarla en el marco de leyes que tienen validez para todos. Le corresponden, por ello, derechos que le aseguran un margen de libre desenvolvimiento y protección contra intromisiones arbitrarias; de acuerdo con esto, le competen deberes frente a otros" —Larenz. Metodología de la ciencia del Derecho. Op. Cit., p. 444-. 
libertades fundamentales. En cambio, la regulación moral con mentiras que se imponen a la verdad puede no tener ninguna consecuencia en la vida de relación social, por ejemplo, la que considera que todas las aberturas para arriba del obligo de la mujer son puras y las que existen para abajo son impuras, salvo las de la virgen, quien es una mujer totalmente pura. De mentiras como esta, que pasan como verdades divinas, se infiere el celibato de curas y monjas con la pretensión de ser personas puras, con sus consecuencias negativas para la Iglesia, por cuanto los que aspiran a curas o monjas prometerán que nunca van a tener relaciones sexuales, pero como son de carne hueso como cualquier otro ser humano, en cualquier momento las tendrán, entonces han pecado y se les sancionará enviando sus almas al infierno, y si las han tenido transgrediendo la ley humana, han delinquido, como sabemos sucede con frecuencia con la pedofilia en la Iglesia. El Derecho en cambio, no regula la conciencia sino la vida de relación social del ser humano, siendo la norma jurídica la barrera de sus acciones $u$ omisiones, es decir, de su libertad; si la persona transgrede la norma se le aplicará la sanción que establece el propio ordenamiento jurídico con el fin de lograr una convivencia pacífica con justicia para todos sus integrantes, creyentes o no en cualquier fe religiosa.

La capacidad jurídica, o capacidad de derechos, expresa Messineo ${ }^{41}$, es un atributo de la personalidad del sujeto y de su existencia, y consiste en la aptitud para ser sujeto de de- rechos subjetivos en general. La capacidad jurídica no es ella misma un derecho subjetivo, sino una cualidad jurídica que es el antecedente lógico de los derechos subjetivos singulares. Es incompatible con la civilización moderna privar al sujeto de su capacidad jurídica general, pero es admisible que se den parciales privaciones de la capacidad jurídica. En tales casos se da una incapacidad jurídica limitada y no una incapacidad de obrar. Así, los extranjeros gozan de los derechos civiles, pero no de los derechos políticos; un niño no goza del derecho de contraer matrimonio, de adoptar, de testar; la legislación fascista había introducido restricciones a la capacidad jurídica, por razones de raza, no permitiendo el acceso a cargos de los hebreos.

En mi fuero interno puedo tener la libertad de querer someter a esclavitud a todos los peruanos indignado por su ineptitud para reaccionar frente al accionar manifiestamente doloso de individuos de las más altas esferas del Gobierno, pero el ordenamiento jurídico haciendo una valoración negativa de tal deseo ha suprimido la institución de la esclavitud. En cumplimiento de su función de prevención de comportamientos antisociales, el ordenamiento jurídico no reconoce a las personas la capacidad jurídica para ser titular del derecho de esclavizar a los demás, o de matar, robar, causar daño a otro, etcétera, pero lo que no puede hacer el Derecho es privar totalmente de su capacidad de goce al ser humano, porque, en tal caso, deja de ser persona ${ }^{42}$.

41. MESSINEO. Manual de Derecho civil y comercial. Op. Cit., Tomo II, pp. 99 y subsiguientes.

42. "Ningún hombre puede carecer, en el Estado, de toda dignidad, porque tendría por lo menos la de ciudadano; excepto cuando la haya perdido por algún crimen y esté todavía en el número de los vivientes convertido en el puro instrumento de la voluntad de otro (sea del Estado, sea de un ciudadano). Ahora bien, aquel que se ha convertido en instrumento de un ciudadano (lo que no puede tener lugar más que por juicio y justicia) es esclavo en el sentido estricto, y forma parte de la propiedad de otro, el cual no solamente es su señor (herus) sino también su propietario (dominus), que puede enajenarle como una cosa y servirse de él como le plazca (con tal que no sea para fines vergonzosos) y que puede disponer de sus fuerzas, pero no de su vida y sus miembros. Nadie puede, por un contrato, obligarse a una dependencia por la cual cese de ser persona; porque solo en cualidad de tal persona se puede contratar. Parece, a la verdad, que un hombre pueda obligarse para con otro por medio de un contrato de servidumbre (mediante salario, alimento o protección) a ciertos trabajos permitidos por su naturaleza, pero indeterminados en cuanto al grado, y por tanto no ser más que súbdito (subjectus) y no esclavo; sin embargo, es falsa esta apariencia. Porque, si el dueño tuviese el derecho de emplear las fuerzas de aquel que está sometido a su voluntad, así como también de agotarlas, hasta que sobreviniese la muerte o hasta la desesperación (tal como sucede con los negros en los ingenios de azúcar), esto no podría tener lugar sino entregándose el enganchado como propiedad a su dueño, lo cual es imposible": KANT. Principios metafísicos del Derecho. Op. Cit., p. 171. 
No se puede confundir capacidad de goce, que es la aptitud para ser titular de derechos y deberes, con capacidad de ejercicio, que es la idoneidad de la persona para realizar actos lícitos o ilícitos, cuyo fundamento se encuentra en la capacidad natural de discernimiento. Tampoco hay que confundir persona física o natural con personalidad o subjetividad jurídica, la cual no depende solamente de la existencia de la persona física, sino de la valoración que de ella haga el ordenamiento jurídico.

Una realidad es el ser humano en su sentido puramente ontológico y otra, su noción jurídica. Una cosa es el ser y otra el deber ser. No hay que confundir al hombre considerado en sí, en su pura realidad natural -material y psicológica-, ideal y cultural, con su derecho a que se le reconozca y proteja su personalidad, sus derechos y deberes inherentes e inviolables. La dignidad del ser humano determina que el Derecho ineludiblemente le reconozca su personalidad jurídica, su capacidad para ser titular de derechos y deberes, su calidad de sujeto de Derecho, nunca de objeto. Como dice Legaz ${ }^{43}$,

"(...) entre persona humana y su noción jurídica existe tanto una relación de deber ser como un vínculo ontológico, quiere decirse que la persona humana debe ser también persona en sentido jurídico y que la persona en sentido jurídico es una entidad, un modo de ser de la persona humana (...) hay un derecho absolutamente fundamental para el hombre, base y condición de todos los demás: el derecho de ser reconocido siempre como persona humana".

Agrega Legaz:

"el orden jurídico debe reconocer a los hombres la personalidad jurídica pero ampli- ficando este concepto de suerte que comprenda tanto la capacidad jurídica como la capacidad (pública y privada) de obrar, pues la capacidad jurídica no es más que un mínimum de personalidad jurídica, lo cual para ser completo debe comprender también la capacidad de obrar en eficacia jurídica (...) el orden jurídico debe atribuir al hombre, conforme a su naturaleza, ciertas libertades y ciertos derechos aún frente al Estado y la comunidad política; los llamados derechos humanos, que protegen la libertad humana y su desenvolvimiento en relaciones determinadas que corresponden a las propiedades naturales del hombre".

La libertad natural no es la misma libertad jurídica, está regula a aquella de acuerdo con ciertas valoraciones en una sociedad determinada y por un cierto tiempo.

La libertad externa es la misma libertad interna, pero ya fenomenalizada, así como la capacidad de goce exteriorizada, ejercitada, es la misma capacidad de goce subjetiva, pero ya objetivada. No porque el sujeto recoge los frutos del fundo de su propiedad, desaparece su capacidad de gozar del atributo de disfrutar del fundo que el Derecho le reconoce, para quedar solamente la capacidad de ejercicio. Solamente se ejercen los derechos subjetivos que se tienen, el sujeto que ejerce un derecho que el ordenamiento jurídico no le otorga o no le reconoce, cae dentro del campo de lo ilícito. El presupuesto de la capacidad de ejercicio es la capacidad de goce ${ }^{44}$, entendida como la aptitud para ser sujeto activo o pasivo de relaciones jurídicas. La capacidad de goce se cristaliza, pero no desaparece, con su ejercicio.

La capacidad de goce no es una pura aptitud, una mera potencialidad, sino que es una ap-

43. LEGAZ Y LACAMBRA. "La noción jurídica de la persona humana y los derechos del hombre". Op. Cit., pp. 20 y subsiguientes.

44. Larenz manifiesta: "La capacidad jurídica del adquirente es el presupuesto para toda adquisición de un derecho; la capacidad para negociar, el presupuesto para la validez de una declaración de voluntad; el poder de disposición sobre el derecho respectivo, el presupuesto para la validez de una disposición" — LARENZ, Karl. Metodología de la ciencia del 
titud potencial o real, efectiva. Por ejemplo, un concebido y un recién nacido tienen real y efectivamente derechos subjetivos que les son reconocidos y tutelados por el ordenamiento jurídico, tienen una efectiva capacidad de goce sobre tales derechos, pero no es posible que todos estos derechos sean ejercitados por su titular, por carecer este de capacidad de ejercicio. Si un adolescente menor de 14 años de edad es propietario de una casa, tiene un poder de goce directo sobre dicho bien, es plenamente consciente que el bien le pertenece en propiedad, y todos los demás sujetos están en el deber de no perturbarlo en el goce pacífico de su derecho, pero no puede realizar sobre él actos de enajenación o gravamen por carecer de "capacidad de ejercicio plena", son incapaces absolutos - artículo 43.1-, no tiene idoneidad para desplegar directamente su propia autonomía negocial y procesal. El ordenamiento jurídico reconoce y tutela a este incapaz de obrar - con capacidad de ejercicio restringida- en su capacidad de goce real, objetivada, como titular del derecho de propiedad, pero no le reconoce la capacidad de ejercicio. Un razonamiento lógico, recto, acorde con la realidad de los hechos, no nos permite, en el ejemplo propuesto, negar que el menor es titular del derecho de propiedad y que disfruta de una capacidad de goce directa sobre el bien que le pertenece, así como no podemos negar que carece de capacidad de ejercicio; por ello, su derecho subjetivo de propiedad es ejercido por sus representantes legales.

Así como no se puede negar que la libertad interna y la libertad fenomenalizada constituyen una unidad y se nos muestran como dos momentos del devenir existencial del ser humano, tampoco se puede negar que la capacidad de goce tiene un aspecto interno y otro objetivado; la capacidad de goce cristalizada no es la capacidad de ejercicio; no todo el que está privado plenamente de capacidad de ejercicio -incapacidad plena o absoluta-, está también privado de capacidad de goce. Un ser humano puede adolecer de una incapacidad plena - absoluta - de ejercicio, pero no puede adolecer de una incapacidad absoluta de goce, dado que ello significaría retroceder a épocas ya superadas de la esclavitud y la pena de muerte civil. La limitación —restriccióno falta de la capacidad de ejercicio del sujeto no incide en la capacidad de goce en cuanto permanece siempre como titular de los derechos que le reconoce el ordenamiento jurídico. La capacidad jurídica es el antecedente de la capacidad de ejercicio. El sujeto privado de determinados derechos subjetivos no puede ejercitarlos ni por sí ni mediante representante, lo cual es lógico, por cuanto no se pueden ejercitar derechos que no se tienen. La incapacidad de goce determina la incapacidad de ejercicio, pero no al contrario. La incapacidad de ejercicio no disminuye la capacidad de goce, es decir, no merma el derecho subjetivo del cual se es titular. Con la incapacidad de ejercicio solamente está en cuestión quién pueda ejercitar el derecho del titular. Los derechos del sujeto que adolece de incapacidad absoluta de ejercicio o de capacidad de ejercicio restringida, salvo las que se encuentran en estado de coma, pueden ser ejercitados por su representante legal.

\footnotetext{
Derecho. Op. Cit.-. Pongamos unos ejemplos: El Presidente de la República no tiene capacidad jurídica para adquirir los bienes nacionales, por tanto, no lo puede hacer ni directa ni indirectamente ni por persona interpuesta —artículo 1366_; el que carece de lucidez mental no tiene el derecho subjetivo de testar —artículo 687.3-, por lo que no puede otorgar testamento ni por sí ni mediante representante; si tuviera el derecho de testar, podría obrar por él su representante legal — su curador- otorgando el testamente respectivo. Las personas no tienen capacidad jurídica para disponer de sus órganos o tejidos mediante venta, dación en pago u otra forma onerosa, por cuanto, "Todo acto de disposición de órganos y/o tejidos, es gratuito. Se prohíbe cualquier tipo de publicidad referida a la necesidad o disponibilidad de un órgano o tejido, ofreciendo o buscando algún tipo de beneficio o compensación" —artículo 7.1 de la Ley 28189-. Si las personas mencionadas, respectivamente, adquirieran los bienes nacionales, testaran o dispusieran de sus órganos o tejidos a título oneroso, estarían obrando sin derecho, es decir, estarían desenvolviendo su personalidad irresponsablemente fuera del marco de libertad que le confiere el ordenamiento jurídico.
} 
Las personas con discapacidad física - parálisis cerebral, pérdida del control motriz, etc.mental ${ }^{45}$ - deterioro mental: senilidad, alzheimer, etc.-, intelectual ${ }^{46}$ - retardo mentalsensorial - ciegos, sordos, ciegosordos, ciegomudos-, requieren contar con ajustes razonables -lentes, audífonos, lenguaje braille, lenguaje por signos, ordenadores electrónicos-, apoyos - una o más personas que lo asistan en su comunicación, comprensión de los actos jurídicos y sus efectos y la manifestación de voluntad-y de salvaguardias - medidas para garantizar el derecho, voluntad y preferencias de la persona que recibe apoyo-. Estas personas discapacitadas gozan de capacidad de goce y de ejercicio plenas.

Desde la perspectiva individualista de la persona natural -el hombre-individuo-, el ser humano es estructuralmente libre, porque tiene vida espiritual es libre ontológicamente. La libertad es "tener en sí mismo la conciencia que él es hoy libertad"47", es la libertad la que permite al ser humano "llegar a ser aquello que puede y quiere ser $^{\prime \prime 48}$. La libertad está adherida en la realidad del ser humano, por ser estructuralmente libre, tenga o no conciencia de ello, se distingue y es superior a los demás seres de la naturaleza. El ser humano es una unidad psicofísica, espiritual y libre, capaz de conocerse a sí mismo y de sentirse distinto a los demás seres de la naturaleza. Pero, aun desde esta perspectiva del hombre-individuo, se tiene que admitir, por ser una verdad innegable, que el ser humano tiene una libertad interior - libertad de conciencia, de creencia, de pensamiento- y otra exterior. La primera radica en la vida psíquica de la persona que la vive y es desconocida por las demás personas que están imposibilitadas de acceder a ella mediante los sentidos o la razón, puede ser limitada únicamente por la propia persona que la vive, determinada por motivaciones internas o externas, pero no puede ser limitada por las demás personas, por cuanto estas no pueden limitar ni suprimir lo desconocido. La limitación de la propia libertad interior solamente se puede lograr parcialmente, verbigracia, una persona, en ejercicio de su libertad, puede tomar la decisión de no pensar más en el mal, pero le está vedado alcanzar este propósito en forma absoluta porque no tiene el control absoluto de sus pensamientos.

En cambio, desde la perspectiva social -el hombre-sociedad - la libertad exterior que es la misma libertad interior exteriorizada, objetivada y como tal conocida, comunicable y perceptible sí puede ser limitada por los demás -ejemplo: con el secuestro, con la aplicación de la pena privativa de la libertad, con la prohibición legal de realizar ciertos actos jurídicos o con la obligación de realizarlos-. Es más, la libertad fenomenalizada nunca es absoluta, dado que siempre está limitada por la acción de la propia persona o por la acción de los demás, por ello es que no se puede hablar de derechos fundamentales ilimitados, con el fin de que todos los seres humanos cuenten con esos derechos. La libertad absoluta es la negación de la libertad. Si se admitiera la libertad absoluta se terminaría con la civilización y el ser humano regresaría al estado de naturaleza, en el cual tiene derecho a todo, esto es, entra a regir la ley de la selva en su plenitud, se termina con la sociedad civil y se entra a vivir en estado de naturaleza, en el cual no hay ley que valga, salvo la del más fuerte. Las concepciones individualistas a ultranza han conducido a justificar los regímenes totalitarios como el nazismo, el fascis-

45. Con la expresión "discapacidad mental" se reemplaza a la expresión "deterioro mental" del derogado inciso 3 del artículo 44.

46. Con la expresión "discapacidad mental" se reemplaza a la expresión "retardo mental" del derogado inciso 2 del artículo 44.

47. KIERKEGAARD, Soren. El contenido de la angustia. Segunda Edición. Buenos Aires: Espasa-Calpe, 1943, p. 118.

48. JASPERS, Karl. La fe filosófica. Buenos Aires: Losada, 1968, p. 60. 
mo, el estalinismo, en los cuales el gobernante ejerce una libertad sin ley.

Escriben los Olano ${ }^{49}$ : Cuenta la historia que un día el filósofo Valerio Carburo fue hasta el Palacio Augusto a visitar al emperador Julio César con el fin de ensalzarlo porque le había dado a los romanos justicia, orden, grandeza y poder, pero sobre todo libertad. Al oír esta palabra, César levanta la cabeza y pregunta al visitante: "¿a qué llamas tú libertad?". "Poder hacer o no hacer lo que se quiere", suena la pronta respuesta. César sacude lentamente la cabeza reflexionando: "Poder hacer o no hacer lo que se debe", corrige. No obstante, agregan estos autores, que en este último concepto se advierte el hálito de una idea ética trascendental, tampoco deja de tener un carácter demasiado general e impreciso. ¿Qué es lo que debe hacer o no hacer el individuo?, la respuesta depende del interés y de la situación peculiar en que se encuentre el individuo en un momento dado, así como de la ideología que influya sobre su concepción del mundo y de la vida. En Francia, la Asamblea Nacional Constituyente de 1789, luego de proclamar que todos los hombres nacen libres e iguales en derechos, definió la libertad -artículo 4- como la facultad de "hacer todo aquello que no cause daño a los demás", deduciendo de este principio general cierto número de libertades particulares: libertad física, libertad de ir y venir —artículo 7-, libertad de conciencia y de opinión - artículo 10-, libertad de pensamiento y de prensa artículo 11-, derecho de propiedad calificado de inviolable y sagrado - artículo 27-.

La magna Asamblea francesa dio todo a la totalidad de los hombres de una sola vez, pero estos no han cesado de disipar tan fabulosa herencia, llegando algunos pensadores a divorciarse de ella. Así, Goethe escribió que la libertad es un bien del hombre que este debe conquistar to- dos los días, como el pan, como la vida misma, coincidiendo con algunos socialistas, quienes afirman que la libertad no existe en estado natural sino que se debe crear día a día, especialmente en los derechos económicos y sociales. Desde el punto de vista jurídico, la libertad está sujeta a las limitaciones del ordenamiento jurídico, la autoridad no puede imponer restricciones que vulneren los principios consagrados en la Constitución. Se garantiza a las personas la libertad frente a los ataques que superen las limitaciones jurídicas.

La lucha por la libertad no tiene fin. Como señala Engels ${ }^{50}$, el Estado se alzó sobre las ruinas de la gens, y agrega:

"Atenas presenta la forma más pura, más clásica; en ella nace el Estado directamente y de una manera preponderante de los antagonismos de clases que se desarrollan en el seno mismo de la sociedad gentil. En Roma, aquella sociedad se convierte en una aristocracia cerrada en medio de una plebe numerosa, mantenida aparte, privada de derechos y llena de deberes; la victoria de la plebe destruye la antigua constitución de la gens e instituye sobre sus ruinas el Estado, donde no tardan en confundirse la aristocracia de la gens y la plebe".

Hay diferentes estadios de emancipación humana. En 1789 se llamó en Francia Revolución al nacimiento de la democracia política, que en el fondo no fue otra cosa que el reconocimiento de los derechos individuales: poder hablar, escribir, votar, ir, venir. Hoy sería el derecho a hablar por televisión o editar un diario sin tener que pasar por las horcas caudinas de la propaganda publicitaria, pero no puede hacer sino quien tenga en sus manos el poder económico o político, el que no lo tiene debe callar o hablar a media voz, ¿se puede negar

49. OLANO, Carlos y OLANO, Hernán. Derecho constitucional e instituciones políticas. Estado social de Derecho. Tercera Edición. Bogotá: Ediciones Librería del Profesional, 2000, pp. 618 y subsiguientes.

50. ENGELS, Federico. El origen de la familia, de la propiedad privada y del Estado. Versión castellana por Juan Antonio de Mendoza. Buenos Aires: Editorial Claridad, 1957, p. 196. 
esa realidad de ayer y de hoy? Afirman los autores Olano que en su propósito de que el concepto de libertad descienda de las abstracciones a las realidades concretas, es oportuno citar a Juan Federico Sciacca, quien precisa que la libertad "es poder hacer todo lo que tienda al desarrollo y perfectibilidad del individuo", definición que alude a los fines y a los medios adecuados para su realización.

El ser humano por el solo hecho de ser tal tiene fines naturales que alcanzar, es una exigencia de su naturaleza; no es natural que un ser humano elija como fin de su vida la ignorancia y la miseria. Al respecto, Burdeau ${ }^{51}$ escribe:

"Se repara en que para una inmensa masa de seres humanos la libertad concebida como una cualidad inherente a su naturaleza no es más que una prerrogativa estéril, desde el momento en que no están en condiciones de disfrutarla efectivamente. ¿Qué importa que el hombre sea libre de pensar, si el expresar su opinión lo expone al ostracismo social; que sea libre de discutir sus condiciones de trabajo, si su situación económica le obliga a plegarse a la ley del patrono; que sea libre de organizar sus diversiones, si la preocupación del pan cotidiano le absorbe todo el tiempo; que sea libre de desarrollar su personalidad por la cultura y la contemplación de un universo abierto a todos, si le falta materialmente el mínimo vital...? El contraste entre la libertad que la filosofía clásica reconocía a su esencia y la servidumbre cotidiana en que le tiene su existencia, conducía así a denunciar como un engaño esta libertad que se pretendía inscrita en la naturaleza humana. La verdad es que la libertad no es un hecho preexistente que hay que proteger: es una facultad que hay que conquistar. A la noción de libertad se sustituye la esperanza de una liberación".

Las libertades faltan si faltan los medios conducentes para ejercitarlas real y efectivamen- te. Es difícil admitir que quien no tiene pan, tiene libertad. Se puede decir que gozan de derechos ilimitados millones de peruanos que, generación tras generación, carecen del derecho a una educación y salud de calidad, a la alimentación, que caminan descalzos, cubiertos con harapos, que año a año mueren con las heladas y friajes, que tienen por casa una pequeña choza donde todos los miembros de la familia duermen juntos y ahí crían sus cuyes y preparan sus escasísimos alimentos. Para ellos esos derechos son una pura imaginación de algunos "juristas", eso no es libertad jurídi$\mathrm{ca}$, eso no es derecho en ningún sentido, una libertad así es nauseabunda que hay que combatirla, para que todo ser humano tenga derechos fundamentales.

El derecho a la libertad está consagrado en la Declaración de los Derechos Humanos formulada por la Organización de Naciones Unidas -artículo 29-; en el artículo 9 del Pacto Internacional de Derechos Civiles y Políticos suscrito en Nueva York, el 16 de diciembre de 1966, que establece: "Todo individuo tiene derecho a la libertad y a la seguridad personales. $\mathrm{Na}$ die podrá ser sometido a detención o prisión arbitrarias. Nadie podrá ser privado de su libertad, salvo por las causas fijadas en la ley y con arreglo al procedimiento establecido en esta". Todas las constituciones modernas consagran el derecho a la libertad. El artículo 13 de la Constitución italiana prescribe: "La libertad personal es inviolable. No se admite ninguna forma de detención, de inspección, o persecución personal, ni cualquier otra forma de restricción de la libertad personal, sino es por mandato motivado de la autoridad judicial". La Constitución peruana, en el artículo 2, establece que toda persona tiene derecho a la libertad de conciencia y de religión, a la libertad de información, opinión, expresión y difusión del pensamiento, a la libertad de creación intelectual, artística, técnica y científica, a la libertad de elegir y ser elegido, de residencia, de reunirse, de asociar-

51. Citado por OLANO, V. y OLANO, G. Derecho constitucional e instituciones políticas. Estado social de Derecho. Op. Cit., p. 622. 
se, de contratar con fines lícitos, etc. El literal a. del inciso 24 del artículo 2, dispone: "Nadie está obligado a hacer lo que la ley no manda, ni impedido de hacer lo que ella no prohíbe", marcando de este modo los límites de la libertad de los ciudadanos. En el mundo civilizado las libertades no son absolutas, sino están limitadas por normas imperativas, el orden público, las buenas costumbres, entre otros límites, con el fin de que todos tengan libertad.

El ordenamiento jurídico confiere capacidad de goce no solamente a la persona natural y al concebido a condición de nazca vivo, sino también a agrupaciones de personas y otros entes, que cumplen con los requisitos establecidos en un momento histórico y en un lugar geográfico; es el Derecho quien decide quienes son sus destinatarios con el fin de que se realice el bien común, por tanto, no se puede negar que tengan derechos y obligaciones las personas jurídicas, verbigracia, el Estado, una sociedad comercial, una cooperativa, una universidad.

Existe una corriente doctrinaria que afirma que las personas jurídicas no tienen capacidad de goce, sino solamente la de ejercicio.

Ihering $^{52}$ escribe:

"Los verdaderos sujetos del derecho, no son las personas jurídicas, sino los miembros aislados; aquellas no son más que la forma especial mediante la cual estos manifiestan sus relaciones jurídicas al mundo exterior, la forma que no tiene importancia alguna para las relaciones jurídicas de los miembros entre sí. Los derechos de cada uno de ellos contra los otros quedan intactos en cuanto en cuanto a la forma. Cada uno puede seguir en vía de acción los derechos adquiridos en virtud de los estatutos, que sólo podrán disputarse o quitarse después de una deliberación de la mayoría. Si la naturaleza misma del lazo que les liga con los miembros de una corporación prohíbe disponer individualmente del fondo común; si las deliberaciones de la mayoría se toman conforme a los estatutos, aunando la voluntad de todos, los derechos individuales de los asociados se separan también en el fondo del tipo de los derechos ordinarios, pero no por eso dejan de ser otros tantos derechos".

Agrega que las fundaciones son una forma más complicada de estas relaciones:

"(...) son por sí mismas el objeto y centro de gravedad de todas las ruedas jurídicas que la hacen mover, pero el eje de todo su mecanismo está en las personas naturales que son las que se deben aprovechar de él. La personificación de las fundaciones es la forma apropiada de un patrimonio a los intereses y a los fines de personas indeterminadas. Los destinatarios de las fundaciones son aquellos en cuyo favor han sido hechas: pobres, enfermos, viudas, huérfanos, protectores de las artes, etc."

Para Kelsen ${ }^{53}$, del mismo modo que la persona "física", la llamada persona "jurídica" es solo la expresión unitaria para un orden jurídico, justamente para aquel que regula la conducta de una pluralidad de hombres. Ora es la personificación de un orden parcial, cuál sería el estatuto de una asociación, el cual constituye una comunidad parcial, la persona jurídica de la asociación; ora es la personificación de un orden jurídico total que constituye una comunidad jurídica comprensiva de todas las comunidades parciales, y que de ordinario está representado en la persona del Estado. La persona jurídica no tiene una existencia natural-real. Real-natural es únicamente la conducta regulada por normas, las que pueden articularse de acuerdo con diversos puntos de vista.

52. VON IHERING, Rudolf. La dogmática jurídica. Traducción de la primera edición alemana: 1883, por Enrique Príncipe y Satorres. Buenos Aires: Editorial Losada, 1946, p. 193.

53. KELSEN, Hans. Op. Cit., pp. 86-87. 
"La hipótesis de que la persona jurídica es una individualidad diferente de los hombres individuales - cosa extraña- sensorialmente no perceptible, o un organismo social supra individual formado por hombres individuales, es la genuina hipotización de un hecho intelectual, de una representación jurídica auxiliar. Así como la persona física no es el hombre, tampoco la persona jurídica es un superhombre. Los deberes y derechos de una persona jurídica tienen que resolverse en deberes y derecho de hombres, esto es, en normas que regulan conducta humana estatuyéndola como deberes y derechos. Que el orden jurídico estatal singular obligue o faculte a una persona jurídica, significa que convierte en deber o en derecho la conducta de un hombre sin determinar el sujeto mismo. Su determinación es dejada, por delegación de parte del orden jurídico estatal, al orden jurídico parcial cuya unidad se expresa en la persona jurídica. Hay una obligación y facultamiento mediato de hombres individuales, es decir, por intermedio del orden jurídico parcial".

En el Perú, Fernández Sessarego ${ }^{54}$, seguidor de esta teoría, citando a Larenz y a Bianca, admite que la capacidad jurídica es aquella de que está dotada la persona "para ser sujeto de relaciones jurídicas y, por ello, titular de derechos y destinatario de deberes jurídicos"; pero no comparte la opinión de Bianca "cuando expresa que dicha capacidad genérica compete también a las personas jurídicas". Afirma, Fernández Sessarego, que desde la vertiente jurídica, "las personas jurídicas solo poseen capacidad de ejercicio".

No compartimos esta teoría negadora de la capacidad de goce de las personas jurídicas, puesto que el ordenamiento jurídico les reconoce la aptitud para ser sujetos de relaciones jurídicas, por ser titulares de derechos y deberes, por supuesto que en forma más limitada que a las personas naturales, lo que resulta obvio.

La capacidad de goce de la persona jurídica, como señala Barbero ${ }^{55}$, no es puramente de índole patrimonial, ni tampoco que en el ámbito patrimonial sea igual al de las personas físicas. La persona jurídica no es ciertamente capaz de relaciones familiares - matrimonio, filiación, adopción, etc.- - Por otra parte tiene como la persona física algunos derechos de la personalidad como el derecho al nombre integridad moral, honor-, tiene un estado de ciudadanía — nacionalidad-, una sede, que hace las veces de domicilio. También en la capacidad patrimonial, hay relaciones que no pueden ser asumidas por las personas jurídicas - no puede ser titular del derecho de habitación-. En conclusión la capacidad de goce de las personas jurídicas es: a) general dentro del ámbito de las relaciones patrimoniales y especial o excepcional respecto de ciertas y determinadas relaciones; b) especial, dentro del ámbito de las relaciones personales y de familia, de manera que en este ámbito, por el contrario, la incapacidad es general.

Precisamente porque la persona jurídica es titular de derechos y deberes puede desplegar su autonomía negocial - celebran todo tipo de contratos-y procesal - actúan como demandantes o demandadas, denunciantes o denunciadas-, mediante sus órganos de gobierno. La capacidad de goce es el presupuesto de la capacidad de ejercicio, por cuanto se ejerce un derecho subjetivo que se tiene; las personas jurídicas no pueden ejercer derechos que no tienen. La capacidad jurídica no es un elemento de la estructura de la naturaleza física o psicológica del ser humano, sino es un atributo conferido por el ordenamiento jurídico al ser humano, a las personas jurídicas y a otros entes para ser titular de derechos y deberes $u$

54. FERNÁNDEZ SESSAREGO, Carlos. Op. Cit., p. 406.

55. BARBERO, Domenico. Sistema del Derecho privado. Tomo I. Introducción. Parte Preliminar - parte general. Traducción de Santiago Sentis Melendo. Buenos Aires: Ejea, 1967, pp. 254-255. 
obligaciones. Las personas jurídicas pueden ser sujetos activos o pasivos de relaciones jurídicas - tienen capacidad de goce- y sus derechos pueden ser ejercidos o sus obligaciones cumplidas por sus órganos de gobierno - tienen capacidad de ejercicio-.

Según el profesor Fernández Sessarego ${ }^{56}$, es equivocado citar como un caso de limitación de la capacidad jurídica, la prohibición impuesta por el artículo 71 de la Constitución al extranjero para adquirir la propiedad, ni directa ni indirectamente, dentro de los cincuenta kilómetros de la frontera ${ }^{57}$, por cuanto tal limitación, según él, no compromete la capacidad genérica o de goce del extranjero, sino que restringe tan solo la capacidad de ejercicio en un tiempo y lugar concretos; agrega que la capacidad de goce en cuanto a ser propietario del extranjero se mantiene y se podrá ejercer cuando se derogue el citado artículo 71. Si seguimos esta línea de "pensamiento", sería válido el absurdo de sostener que una persona tiene la potencial capacidad de goce para ser propietaria del Perú, esclavizar a los peruanos por ser tolerantes con la corrupción política, contraer matrimonio cuantas veces lo desee no obstante que ser casada, matar a sus enemigos, violar a la persona de sexo contrario, pero que por ahora está limitada a ejercer su inherente capacidad de goce de esos "derechos", limitación que será eliminada cuando se deroguen las leyes que lo prohíben; y que cuando se deroguen tales disposiciones, no es que la persona recuperará su capacidad de goce, porque nunca la perdió, sino que solo se le restituye su capacidad de ejercicio, es decir, de ejercer concretamente su derecho de ser dueño del Perú, esclavizar a los demás, casarse no obstante que es casado, matar a sus enemigos, violar sexualmente a quien le plazca. Sin duda, esto significaría la fuga del ser humano del estado de civilización al estado de naturaleza, en el que la libertad es ilimitada y el Derecho no tiene razón de existir, por cuanto no tiene nada que regular. Los que así piensan, totalmente fuera del Derecho, han modificado el artículo 3 del Código estableciendo que la capacidad de goce no se puede limitar, sino solamente la de ejercicio. Esta es la consagración legal de la mentira como verdad. Afirmar que solamente se puede limitar la capacidad de ejercicio, mas no la de goce, es una pura idealidad desconectada totalmente de la realidad jurídica — realidad natural calificada por el Derecho-, por ejemplo, cuando la ley priva o limita nuestra libertad, prohibiéndonos contratar con fines ilícitos; nos obliga a pagar impuestos; dispone que determinadas autoridades no pueden adquirir los bienes nacionales por contrato, legado, directa o indirectamente o por interpósita persona; impone la pena privativa de la libertad al delinque; prohíbe el matrimonio entre consanguíneos en línea recta.

Los derechos subjetivos son los que el ordenamiento jurídico reconoce, atribuye, garantiza y tutela a los sujetos de Derecho ${ }^{58}$. No es concebible que algunos derechos fundamentales

56. FERNÁNDEZ SESSAREGO, Carlos. El Derecho de las personas (en el umbral del siglo XXI). Lima: Ediciones Jurídicas, 2002, pp. 415-416.

57. El segundo párrafo del artículo 71 del Constitución de 1993 prescribe: "Sin embargo, dentro de los cincuenta kilómetros de las fronteras, los extranjeros no pueden adquirir ni poseer, por título alguno, minas, tierras, bosques, aguas, combustibles ni fuentes de energía, directa ni indirectamente, individualmente ni en sociedad, bajo pena de perder, en beneficio del Estado, el Derecho así adquirido. Se exceptúa el caso de necesidad pública expresamente declarada por decreto supremo aprobado por el Consejo de Ministros de acuerdo a ley".

58. Messineo expresa: "El derecho subjetivo presupone el Derecho objetivo, u ordenamiento jurídico constituido, que le presta el fundamento y justificación. El derecho subjetivo puede actuarse (agere licere), no ya porque su titular tenga la fuerza de actuarlo (agere posse), sino porque es concedido por la norma, la cual eventualmente se vale, ella, de la fuerza (posse), para garantizar los derechos subjetivos y restaurarlos, en caso de haber sido violados" —MESSINEO, Francesco. Manual de Derecho civil y comercial. Op. Cit., Tomo II, p. 9-. 
básicos como el de la dignidad de la persona y todos los inherentes a ella, solo se reconozcan a algunas personas en las que concurren determinadas condiciones. Pero esto no significa que existan derechos que como los referidos a la actuación en el ámbito del Estado, las constituciones como la peruana de 1993, los reconozcan solamente a los nacionales y no a los extranjeros, por ejemplo, para ser congresista, presidente de la República, magistrado de la Corte Suprema se requiere ser peruano de nacimiento -artículos 90, 110 y 147.1-. Frente a estas disposiciones no se puede argumentar que los extranjeros no han sido privados de su aptitud de gozar de estos cargos, sino que están solamente limitados temporalmente para ejercerlos; que en un futuro cuando se deroguen estas normas se les restituirá su específica capacidad de ejercicio para la actuación de su capacidad genérica a ser congresistas, presidente, magistrado de la Corte Suprema. Una argumentación así no es jurídica, puesto que, contrariamente al artículo 3 del Código que dispone que la capacidad de goce no se puede restringir, el ordenamiento jurídico priva o limita la capacidad de goce respecto de determinados hechos o actos jurídicos, como los antes señalados.

La actuación y la utilización de la capacidad de goce se consigue mediante su ejercicio, es decir, desarrollando los poderes, las facultades, atribuciones, autorizaciones, en una palabra, ejerciendo los derechos subjetivos que el ordenamiento reconoce o confiere al sujeto. No hay ejercicio de la nada, sino ejercicio de un derecho subjetivo, que es tal solamente cuando el Derecho lo reconoce o confiere al sujeto. El contenido, la materia, de la capacidad de ejercicio es la capacidad de goce, es decir, los derechos subjetivos y los correlativos deberes u obligaciones; fuera del Derecho positivo no hay derechos, sino solamente deberes morales o de otra naturaleza extrajurídica. La falta de ejercicio del derecho más allá de los plazos fijados por el ordenamiento puede dar lugar a la extinción del derecho por prescripción o caducidad.

Como hemos señalado, la capacidad de goce opera dentro del ámbito reconocido por el ordenamiento jurídico. El Derecho no reconoce al sujeto una capacidad de goce ilimitada, incondicionada, porque ello significaría simplemente un retorno al estado de naturaleza donde el hombre tiene el derecho absoluto a todo, prevaleciendo la ley del más fuerte. La capacidad de goce es un atributo reconocido por el ordenamiento jurídico al ser humano, a la persona, desde que es concebido hasta que muere, se es ser humano más o menos capaz, pero no se es más o menos ser humano. En este sentido, Barbero ${ }^{59}$, quien distingue entre personalidad jurídica y capacidad jurídica — de goce-, explica que la "personalidad jurídica" es una calificación formal por efecto de la cual un ente se considerará "sujeto de derecho". La personalidad jurídica y la capacidad jurídica son distintas: la personalidad jurídica es un quid simple; mientras la "capacidad" es un quantum y, por tanto, susceptible de medición por grados. Se puede ser, como "persona", más o menos "capaz"; no se puede ser más o menos "persona". Persona se es o no se es: totalmente, radicalmente. De manera que a propósito de las "personas jurídicas", dicho sea aquí per incidens, quien ha distinguido entre una personalidad plena y una personalidad limitada o atenuada, está atrapado en esa confusión, tomando la "personalidad del ente" por la "capacidad de la persona" —o por la "autonomía patrimonial"-.

Aun identificando personalidad jurídica y capacidad goce se llega a la conclusión de que se puede ser persona más o menos capaz, pero no se puede ser más o menos persona, dado que la personalidad jurídica o la capacidad de goce no son caracteres de la persona o individuo en cuanto tal, no son elementos de su naturaleza psicobiológica, sino que le son atribuidas por una norma de organización, previa valorización de su idoneidad para ser 
destinataria de derechos y deberes; por consiguiente, el individuo como tal es una realidad y otra realidad es su capacidad atribuida por el Derecho en mayor o menor grado. El ser humano - el individuo - es total, radicalmente, o no es; en cambio, su capacidad de goce opera solamente dentro de los límites fijados por el Derecho. Una capacidad natural -no jurídica- ilimitada, sin ley, no corresponde a una sociedad humana civilizada, sino a una sociedad en estado de naturaleza, donde no impera el Derecho, sino la ley del más fuerte.

La capacidad de goce es reconocida por el Derecho al ser humano sobre la base de su naturaleza misma. Pero el Derecho, por razones superiores, puede privar o limitar esa capacidad, es decir, puede privar o limitar al ser humanos determinados derechos subjetivos, y, en otras ocasiones, en cambio, puede atribuir una cierta capacidad de goce a entes distintos del ser humano que no tienen una estructura psicofísica. Así, por disposición del ordenamiento jurídico, un ente colectivo puede tener una capacidad de goce, por supuesto más limitada que la del ser humano, tribuida por el Derecho público o privado. Veamos dos ejemplos:

a) El artículo 21 del Decreto Supremo № 1332013-EF, Texto Único Ordenado del Código Tributario, publicado el 19 de agosto de 99, dispone:

"Artículo 21. Capacidad Tributaria. Tienen capacidad tributaria las personas naturales o jurídicas, comunidades de bienes, patrimonios, sucesiones indivisas, fideicomisos, sociedades de hecho, sociedades conyugales $u$ otros entes colectivos, aunque estén limitados o carezcan de capacidad o personalidad jurídica según el Derecho privado o público, siempre que la ley le atribuya la calidad de sujetos de derechos y obligaciones tributarias".

b) El contrato asociativo de consorcio o joint venture no genera una persona jurídica distinta de los contratantes -artículo 438 de la Ley General de Sociedades, Ley 26887-, o sea genera solamente una re- lación contractual entre los consorciados, tan igual como un contrato de compraventa genera una relación contractual entre vendedor y comprador; en tal virtud, por su propia naturaleza de relación contractual y por así disponerlo la Ley 26887, el consorcio carece de personalidad jurídica, no es sujeto de Derecho, no tiene capacidad goce general, los titulares de los derechos y obligaciones que nacen del consorcio son las partes contratantes. Sin embargo, el Decreto Legislativo 774, Ley del Impuesto a la Renta, modificado por Ley 27034, en su artículo 14, inciso k, dispone que se considera persona jurídica al joint venture que lleve contabilidad independiente de las partes contratantes, $y$, por tanto, debe liquidar y determinar el impuesto a la renta en cabeza del contrato, o sea por disposición de la Ley, el contrato de joint venture es sujeto de derecho para efectos tributarios, tiene capacidad de goce tributaria — capacidad jurídica especial- por estar afecto al impuesto de tercera categoría.

El ser humano es el sujeto por excelencia de las relaciones jurídicas, lo que presupone la personalidad jurídica o capacidad jurídica. Pero el ser humano - la persona - es mucho más que su vida social regulada por el Derecho, es también su vida social no regulada por el Derecho, además de la inmensidad de su vida individual y de su vida psíquica, que son ajenas al Derecho. El ser humano es sujeto de Derecho desde su concepción hasta su muerte. El concebido es titular de derechos - puede adquirir bienes por herencia, legado o donación, tiene derecho a los alimentos; si por dolo o culpa de un tercero fallecen, sus padres y él, si logra sobrevivir, tienen derecho a una indemnización; tiene derecho a ser indemnizado por los daños que sufra mientras se encuentra en el seno materno, puede ser reconocido como hijo extramatrimonial, puede ser beneficiario de un contrato de seguro, puede contraer obligaciones correlativas a los derechos patrimoniales adquiridos, etc., a condición de que nazca vivo-; por consiguiente, es sujeto de relaciones jurídicas, o sea, es un actor de la vida social, como lo es un sujeto nacido menor 
o mayor de edad, por lo que, en nuestra opinión, es una "persona ${ }^{60}$ humana", aunque para el Código Civil no lo es sino a partir del nacimiento, lo que no es más que una ficción que se mantiene en muchas legislaciones; no obstante que para el Código el concebido no es persona, pero no por eso puede ser considerado como menos ser humano que un ser humano nacido. Los derechos no patrimoniales del concebido son incondicionados y los patrimoniales están sujetos a la condición resolutoria, no suspensiva, de que nazca vivo. Siendo el concebido un sujeto de Derecho para todo cuanto le favorezca tiene una capacidad de goce más limitada que la del nacido, pero no por eso es menos vida humana.

A la naturaleza psicofísica del ser humano, nacido o por nacer, el ordenamiento jurídico le reconoce personalidad jurídica con la que deviene en sujeto de Derecho titular de deberes jurídicos y derechos subjetivos, a fin de cuentas es el ordenamiento jurídico el que reconoce o atribuye capacidad goce a la persona física, quien no puede ser sujeto sin capacidad de goce. El hombre ha creado el Derecho para hacer posible una vida de relación ordenada, pacífica y justa, y por esas razones superiores puede privar o limitar de ciertos derechos al ser humano. Como dice Barbero, el sujeto no es solamente su capacidad jurídica y su capacidad de actuar, sino antes que todo esto, el sujeto es un prius del ordenamiento jurídico: no porque existe el ordenamiento jurídico vienen a existir esos sujetos, sino porque existen esos sujetos viene a existir y existe el ordenamiento jurídico ${ }^{61}$.

Es una verdad innegable que el ordenamiento jurídico priva o limita la capacidad de goce respecto de ciertos derechos, hechos o actos jurídicos.

\section{Capacidad de ejercicio de las personas con discapacidad.}

El último párrafo del artículo 3 establece que "(...) las personas con discapacidad tienen capacidad de ejercicio en igualdad de condiciones en todos los aspectos de la vida", texto según Decreto Legislativo 1384, publicado el 4 de setiembre de 2018. Esta norma aborda la institución de la capacidad de ejercicio de las personas con discapacidad - llamada también: diversidad funcional-para acomodarla a los nuevos planteamientos establecidos por la Convención sobre los Derechos de la Personas con Discapacidad —en adelante, la "Convención" - aprobada en el $2006^{62}$, de la cual el Perú es parte.

También con el fin de adaptar la legislación nacional a la Convención se ha dado la Ley 9973, Ley General de la Persona con Discapacidad, publicada el 29 de noviembre de 2017, que contiene la siguiente definición:

"La persona con discapacidad es aquella que tiene una o más deficiencias físicas, sensoriales, mentales o intelectuales de carácter permanente que, al interactuar con diversas

60. La palabra "persona" proviene de una voz latina idéntica, tomada de la máscara que usaban los actores de aquel tiempo, empleada también para resonar más la voz — del verbo personare-, de donde pasó a significar el propio actor, luego el personaje representado y finalmente el ser humano, protagonista de la vida, actor de este gran teatro del mundo. Como tecnicismo no parece haberse aplicado el término hasta los tiempos del emperador Teodosio II y para contraponerlo al esclavo, ser carente de derechos y obligaciones, aunque no de cargas y trabajos. Personalidad es la aptitud legal para ser sujeto de derechos y obligaciones; también significa la diferencia individual que distingue a cada uno de los demás, o el carácter bien definido de cada ser humano.

61. BARBERO, Doménico. Tomo I. Op. Cit., p. 189.

62. Convención Internacional sobre los Derechos de las Personas con Discapacidad, aprobada por la Organización de las Naciones Unidas, en la ciudad de Nueva York, el 13 de diciembre de 2006. El Perú firmó la Convención el 30 de marzo de 2007. Fue aprobada por el Congreso de la República mediante Resolución Legislativa N 29127 del 30 de noviembre 2007, publicada el 1 de noviembre de 2007 y ratificada por el Presidente de la República, según Decreto Supremo Nº 073-2007-RE del 30 de diciembre de 2007, publicado el 31 de diciembre 2007. Entró en vigor el 3 de mayo de 2008. 
barreras actitudinales y del entorno, no ejerza o pueda verse impedida en el ejercicio de sus derechos y su inclusión plena y efectiva en la sociedad, en igualdad de condiciones que las demás" - artículo 2-.

Como parte de la Convención, el Estado peruano debe realizar las acciones tendientes a eliminar los obstáculos para la igualdad y participación activa de las personas con discapacidad en todos los ámbitos de la vida social, política, económica, cultural, tecnológica, en igualdad de condiciones con las demás personas.

Las personas discapacitadas tienen la misma capacidad de goce - rasgo propio de la dignidad de la persona-y de ejercicio que los demás, debiendo eliminarse las prácticas sociales que las discriminan en razón de su discapacidad, procurando que cuenten con la posibilidad de actuar con autonomía e independencia individual y tomar sus propias decisiones en todos los aspectos de la vida, promoviendo el respeto de su dignidad inherente. Para el efecto, el Estado tomará las medidas para dotarles el apoyo de terceros que lo ayuden o asistan en la toma de decisiones, estableciendo las salvaguardias necesarias contra el abuso de dicho apoyo, de tal modo que nadie vea suprimida o limitada arbitrariamente su capacidad de ejercicio.

Se pasa del modelo tradicional de la sustitución, mediante la representación, al modelo de apoyo o asistencia al discapacitado en la toma de decisiones. Es decir, de la incapacidad de la persona, como consecuencia de sus deficiencias físicas, mentales, intelectuales o sensoriales a largo plazo, se pasa a su capacidad con la ayuda de reajustes razonables, apoyos y salvaguardias; solamente si no es posible recuperar su capacidad de manifestar su voluntad, el juez le nombrará un representante.

Las deficiencias físicas — pérdida motriz, disfunción del sistema locomotor, parálisis parcial o total del cuerpo, parálisis cerebral, etc.-, mentales - deterioro o debilidad mental: alzhéimer, demencia senil, párkinson, etc.-, intelectuales - retardo o retraso mental-o sensoriales - merma o pérdida de la facultad de sentir: sordos, ciegos, ciegosordos, ciegomudos-, para que generen discapacidad que afecta a la capacidad, deben ser de largo plazo. Pueden ser originarias, el ser humano nace con esas deficiencias, o sobrevinientes. Cuando son graduales, verbigracia, la senilidad, la persona que desplegaba sus facultades a plenitud, va perdiendo gradualmente su capacidad de autogobierno hasta su total desaparición, pierde poco a poco sus facultades de actuar por sí misma en su vida cotidiana y jurídica, por lo que va a necesitar de apoyo para ello, hasta desembocar en una incapacidad total, caso en el que el juez le designará un representante que actúe porél.

La capacidad de un discapacitado, sin o con apoyos, se presume, la incapacitación se declara judicialmente y conduce a la representación legal.

El artículo 1 de la Convención dispone:

"El propósito de la presente Convención es promover, proteger y asegurar el goce pleno y en condiciones de igualdad de todos los derechos humanos y libertades fundamentales por todas las personas con discapacidad, $y$ promover el respeto de su dignidad inherente. Las personas con discapacidad incluyen a aquellas que tengan deficiencias físicas, mentales, intelectuales o sensoriales a largo plazo que, al interactuar con diversas barreras, puedan impedir su participación plena y efectiva en la sociedad, en igualdad de condiciones con las demás".

En el marco de esta norma de la Convención, el artículo 3 de la Ley 29973 dispone:

"Artículo 3. Derechos de la persona con discapacidad. 3.1 La persona con discapacidad tiene los mismos derechos que el resto de la población, sin perjuicio de las medidas específicas establecidas en las normas nacionales e internacionales para que alcance la igualdad de hecho. El Estado garantiza un entorno propicio, accesible y equitativo para su pleno disfrute sin discriminación. 3.2 Los derechos 
de la persona con discapacidad son interpretados de conformidad con los principios y derechos contenidos en la Declaración universal de los Derechos Humanos, la Convención sobre los Derechos de las Personas con Discapacidad y con los demás instrumentos internacionales sobre derechos humanos ratificados por el Perú."

Las personas con discapacidad, conforme a los artículos 3, 42 y 46 del Código, tienen plena capacidad de goce en todos los aspectos de la vida, en igualdad de condiciones con las demás personas no discapacitadas. Cuando cumplen 18 años de edad adquieren su plena capacidad de ejercicio, independientemente de si usan o requieren de ajustes razonables o de apoyos para la manifestación de su voluntad. Excepcionalmente tienen plena capacidad de ejercicio los mayores de 14 años y menores de 18 años que contraigan matrimonio o quienes ejerciten la paternidad a esa edad sin haber contraído matrimonio. Las personas con discapacidad tienen igual capacidad de goce y de ejercicio que las personas sin discapacidad.

Se reconoce y garantiza a todas las personas con cualquier tipo de discapacidad, sea por deficiencias físicas, mentales, intelectuales o sensoriales a largo plazo, el goce de todos los derechos humanos y libertades fundamentales, el respeto de su dignidad inherente, su autonomía individual, su libertad para tomar sus propias decisiones, su derecho a una vida independiente, a una plena y efectiva participación en la sociedad, en un plano de igualdad de condiciones con las demás personas.

El artículo 3 de la Convención consagra como principios generales, que constituyen el marco legislativo de protección de los derechos de las personas con discapacidad, a los siguientes: “a) El respeto de la dignidad inherente, la autonomía individual, incluida la libertad de tomar las propias decisiones, y la independencia de las personas;

b) La no discriminación;

c) La participación e inclusión plenas y efectivas en la sociedad;

d) El respeto por la diferencia y la aceptación de las personas con discapacidad como parte de la diversidad y la condición humanas;

e) La igualdad de oportunidades;

f) La accesibilidad;

g) La igualdad entre el hombre y la mujer;

h) El respeto a la evolución de las facultades de los niños y las niñas con discapacidad y de su derecho a preservar su identidad".

Entre estos principios destaca el respecto a la autonomía personal, la igualdad de oportunidades, la accesibilidad ${ }^{63}$ y la no discriminación, el respeto por la diferencia y la aceptación de las personas con discapacidad como parte de la diversidad y la condición humanas. Con ello se tiende a construir una sociedad con derechos para todos, lo que implica trabajar para lograr que las personas con discapacidad tengan una efectiva igualdad de oportunidades en todos los aspectos de la vida. La inclusión y participación en la comunidad de las personas con discapacidad en igualdad de derechos con las sin discapacidad, y el reconocimiento y aceptación de la diversidad de cada ser humano como algo natural y enriquecedor para todos son los requisitos esenciales para la creación de una sociedad justa y respetuosa.

Nuestro país por ser parte de este tratado está en la obligación de hacer las adaptaciones legales y los ajustes de políticas necesarias para, haciendo realidad estos principios, garantizar que las personas con discapacidad puedan disfrutar de todos los derechos en igualdad de condi-

63. Ley 29973: "Artículo 15. Derecho a la accesibilidad. La persona con discapacidad tiene derecho a acceder, en igualdad de condiciones que las demás, al entorno físico, los medios de transporte, los servicios, la información y las comunicaciones, de la manera más autónoma y segura posible. El Estado, a través de los distintos niveles de gobierno, establece las condiciones necesarias para garantizar este derecho sobre la base del principio de diseño universal. Asimismo tiene derecho a gozar de ambientes sin ruidos y de entornos adecuados". Ver también artículo 16 -modificado por el Artículo Único de la Ley 30603-y siguientes. 
ciones con las demás personas que no sufren discapacidad.

La Convención dispone que las personas con discapacidad tienen la misma capacidad de goce y de ejercicio que las demás personas; los Estados están obligados a adoptar las medidas pertinentes para proporcionar el acceso de las personas con discapacidad al apoyo que puedan necesitar en el ejercicio de su capacidad jurídica, medidas que deberán ser proporcionales al grado de discapacidad. El artículo 12 de la Convención prescribe:

"Artículo 12 lgual reconocimiento como persona ante la ley.

1. Los Estados Partes reafirman que las personas con discapacidad tienen derecho en todas partes al reconocimiento de su personalidad jurídica.

2. Los Estados Partes reconocerán que las personas con discapacidad tienen capacidad jurídica en igualdad de condiciones con las demás en todos los aspectos de la vida.

3. Los Estados Partes adoptarán las medidas pertinentes para proporcionar acceso a las personas con discapacidad al apoyo que puedan necesitar en el ejercicio de su capacidad jurídica.

4. Los Estados Partes asegurarán que en todas las medidas relativas al ejercicio de la capacidad jurídica se proporcionen salvaguardias adecuadas y efectivas para impedir los abusos de conformidad con el derecho internacional en materia de derechos humanos. Esas salvaguardias asegurarán que las medidas relativas al ejercicio de la capacidad jurídica respeten los derechos, la voluntad y las preferencias de la persona, que no haya conflicto de intereses ni influencia indebida, que sean proporcionales y adaptadas a las circunstancias de la persona, que se apliquen en el plazo más corto posible y que estén sujetas a exámenes periódicos por parte de una autoridad o un órgano judicial competente, independiente e imparcial. Las salvaguardias serán proporcionales al grado en que dichas medidas afecten a los derechos e intereses de las personas.

5. Sin perjuicio de lo dispuesto en el presente artículo, los Estados Partes tomarán todas las medidas que sean pertinentes y efectivas para garantizar el derecho de las personas con discapacidad, en igualdad de condiciones con las demás, a ser propietarias y heredar bienes, controlar sus propios asuntos económicos y tener acceso en igualdad de condiciones a préstamos bancarios, hipotecas y otras modalidades de crédito financiero, y velarán por que las personas con discapacidad no sean privadas de sus bienes de manera arbitraria"64.

Se deduce de esta norma que los discapacitados tienen igual capacidad de goce y de ejercicio que los no discapacitados, tienen derecho a la igualdad ante la ley y a no ser discriminados por su incapacidad. En este marco convencional, la Ley 29973 prescribe que el Estado garantiza el derecho de la persona con discapacidad a la propiedad, a la herencia, a contratar libremente y a acceder en igualdad de condiciones que las demás a seguros, préstamos bancarios, hipotecas y otras modalidades de crédito financiero. Asimismo, garantiza su derecho a contraer matrimonio y a decidir

64. En conformidad con esta norma de la Convención, el artículo 4 de la Ley 29973 prescribe: "Artículo 4. Principios rectores de las políticas y programas del Estado. 4.1 Las políticas y programas de los distintos sectores y niveles de gobierno se sujetan a los siguientes principios: a) El respeto de la dignidad inherente; la autonomía individual, incluida la libertad de tomar las propias decisiones; y la independencia de la persona con discapacidad. b) La no discriminación de la persona con discapacidad. c) La participación y la inclusión plenas y efectivas en la sociedad de la persona con discapacidad. d) El respeto por la diferencia y la aceptación de la persona con discapacidad como parte de la diversidad y la condición humanas. e) La igualdad de oportunidades para la persona con discapacidad. f) La accesibilidad.g) La igualdad entre el hombre y la mujer con discapacidad. h) El respeto a la evolución de las facultades del niño y la niña con discapacidad y de su derecho a preservar su identidad. i) La razonabilidad. j) La interculturalidad. 4.2 Los distintos sectores y niveles de gobierno incluyen la perspectiva de discapacidad en todas sus políticas y programas, de manera transversal." 
libremente sobre el ejercicio de su sexualidad y su fertilidad —artículo 9-; el discapacitado tiene derecho a vivir en forma independiente en la comunidad, en igualdad de condiciones que los demás, debiéndose facilitar su inclusión familiar y social; tiene derecho a participar en la vida política y pública, directamente o a través de representantes libremente elegidos, incluyendo el derecho a elegir y ser elegido, a desempeñarse en cualquier función pública -artículo 13-. Los discapacitados, en igualdad con los no discapacitados, gozan de todos los derechos detallados en el artículo 2 de la Constitución, lo que "no excluye los demás que la Constitución garantiza, ni otros de naturaleza análoga o que se funden en la dignidad del hombre, o en los principios de soberanía del pueblo, del Estado democrático de derecho y de la forma republicana de gobierno" - artículo 3 de la Constitución-.

Es nulo todo acto discriminatorio por motivos de discapacidad que afecte los derechos de las personas; se considera como tal toda distinción, exclusión o restricción por motivos de discapacidad que tenga el propósito o el efecto de obstaculizar o dejar sin efecto el reconocimiento, goce o ejercicio, en igualdad de condiciones, de uno o varios derechos, incluida la denegación de ajustes razonables. No se consideran discriminatorias las medidas positivas encaminadas a alcanzar la igualdad de hecho de la persona con discapacidad —artículo 8 de la Ley 29973-.

El Estado debe adoptar las medidas para que el discapacitado tenga acceso a apoyos y salvaguardias para el ejercicio de su capacidad jurídica, considerando que el sistema de protección del discapacitado no es el de la sustitución en la toma de sus decisiones, sino el sistema de apoyos y salvaguardias para el ejercicio de su capacidad jurídica. En otros términos, al reconocer que el discapacitado tiene igual capacidad de goce y de ejercicio que las demás personas no discapacitadas, se les debe proteger no asignándoles un tutor o curador, sino apoyos y salvaguardias para garantizar su autonomía personal.

El derecho de las personas con discapacitados a vivir en forma independiente y a ser incluidos en la comunidad es recogido en el artículo 19 de la Convención ${ }^{65}$. Se reconoce el derecho en igualdad de condiciones de todas las personas con discapacidad a vivir en la comunidad, con las mismas opciones de las demás, debiendo el Estado adoptar las medidas efectivas y pertinentes para facilitar el pleno goce de este derecho a los discapacitados y su plena inclusión y participación en la comunidad, asegurándoles que:

a) tengan la oportunidad de elegir su lugar de residencia, dónde y con quién vivir, en igualdad de condiciones con las demás personas, y no se vean obligadas a vivir con arreglo a un sistema de vida específico;

b) tengan acceso a una variedad de servicios de asistencia domiciliaria, residencial y otros servicios de apoyo de la comunidad, incluida la asistencia personal que sea necesaria para facilitar su existencia y su inclusión en la comunidad y para evitar su aislamiento o separación de ésta;

c) las instalaciones y los servicios comunitarios para la población en general tengan en cuenta sus necesidades y estén a su disposición, en igualdad de condiciones con las demás personas no discapacitadas.

65. Ley 29973: "Artículo 11. Derecho a vivir de forma independiente y a ser incluida en la comunidad. 11.1 La persona con discapacidad tiene derecho a vivir de forma independiente en la comunidad, en igualdad de condiciones que las demás. El Estado, a través de los distintos sectores y niveles de gobierno, promueve su acceso a servicios de asistencia domiciliaria, residencial y otros servicios de apoyo en la comunidad para facilitar su inclusión social y evitar su aislamiento y abandono. 11.2 Los establecimientos que prestan atención a las personas con discapacidad promueven y facilitan su inclusión familiar y social." 
Las personas con discapacidad son titulares de todos los derechos, tienen capacidad de goce plena en igualdad de condiciones con las demás personas y cuentan con capacidad para ejercer tales derechos. No son objeto de simples políticas asistenciales que denotan un perfil de beneficencia y solidaridad, antes que un verdadero respeto de sus derechos fundamentales. El discapacitado, especialmente el que adolece de dificultades mentales, intelectuales o sensoriales, al igual que el no discapacitado, tiene capacidad de goce y también capacidad de obrar, para poder ejercer sus derechos y asumir obligaciones sin tener que recurrir a un representante, sino tomando sus decisiones autónomamente con la asistencia de apoyos.

\section{Como señalan López Ruiz ${ }^{66}$,}

“(...) la inclusión y participación de las personas con discapacidad en la comunidad en igualdad de derechos a sus conciudadanos sin discapacidad, es fundamental para crear una sociedad más justa y respetuosa. Por lo que es esencial que aprendamos a aceptar la diversidad de cada ser humano como algo natural y enriquecedor para todos. Para conseguirlo debemos hacer más visible la discapacidad, o dicho de otra manera, debemos normalizar la discapacidad a través de programas educativos, campañas de sensibilización, etc. que derriben los prejuicios y estereotipos que impiden la libre participación de las personas con discapacidad y se les reconozcan los derechos humanos, civiles y políticos que, hoy en día se les sigue negando".

El artículo 21 de la Ley 29973 regula la accesibilidad en la comunicación de las personas discapacitadas, disponiendo que el Estado les garantiza el acceso y la libertad de elección respecto a los distintos formatos y medios utilizables para su comunicación. Estos inclu- yen la lengua de señas, el sistema braille, la comunicación táctil, los macrotipos, la visualización de textos, los dispositivos multimedia, el lenguaje escrito, los sistemas auditivos, el lenguaje sencillo, los medios de voz digitalizada y otros modos y medios aumentativos o alternativos de la comunicación. La persona con discapacidad tiene derecho a utilizar la lengua de señas, el sistema braille y otros formatos o medios aumentativos o alternativos de comunicación en los procesos judiciales y en los administrativos; para tal fin, las entidades públicas les proveerán, de manera gratuita y en forma progresiva, el servicio de intérprete cuando esta lo requiera. Las entidades públicas, los prestadores de servicios públicos, las administradoras de fondos de pensiones y las entidades bancarias y financieras y de seguros remiten información, recibos y estados de cuenta en medios y formatos accesibles al usuario con discapacidad que lo solicite.

La accesibilidad de los discapacitados en la contratación de la Administración está prevista en el artículo 24 de la citada ley:

\section{"Artículo 24. Accesibilidad en la contratación de bienes, servicios u obras. Las bases de los procesos de selección para la contratación de bienes, servicios u obras por parte de las entidades públicas deben sujetarse a la nor- mativa vigente en materia de accesibilidad para personas con discapacidad, según co- rresponda".}

Las personas con deficiencias físicas, mentales, intelectuales o sensoriales no son las que tienen que superar por sí solas estas dificultades para gozar de capacidad de goce y de ejercicio y que si no lo logran al nivel de una persona sin discapacidad se les anule o relativice su capacidad, privándolo de su derecho de manifestar su voluntad, sustituyéndolo por un representante, sino es la sociedad la que debe adaptarse

66. LÓPEZ, Mercedes y RUIZ, Susana. "Derecho a vivir de forma independiente y ser incluido en la comunidad." En: La Convención Internacional sobre los Derechos de las Personas con Discapacidad. Directora: Esperanza Alcain Martínez, Coordinadora: Gloria Álvarez Ramírez. Valencia: Tirant lo Blanch, 2015. Disponible en: <http://www.convenciondiscapacidad.es/wp-content/uploads/2017/09/75 Actas congreso-ilovepdf-compressed.pdf $>$. 
a la situación de discapacidad ${ }^{67}$, estableciendo: ajustes razonables que permitan ayudar al discapacitado a superar obstáculos o dificultades para su inclusión social, cultural, laboral ${ }^{68}$, educacional, deportiva, etcétera. Las personas con discapacidad que manifiesten su voluntad pueden contar con apoyos ${ }^{69}$ y salvaguardias designados judicial o notarialmente y las que no pueden manifestar su voluntad podrán contar con apoyos y salvaguardias designados judicialmente -incisos 1 y 2 del artículo 45-b-, figuras tuitivas que no sustituyen la voluntad de los discapacitados, sino que les prestan asistencia para el ejercicio de su capacidad de obrar, a fin que puedan acceder a todos sus derechos en igualdad de condiciones en todos los aspectos de la vida.

Se produce un cambio fundamental en la forma de abordar la capacidad de ejercicio de las personas con discapacidad que necesiten del apoyo de terceros para la toma de sus decisio- nes. Se cambia el modelo de la sustitución de la persona, mediante la designación de un representante, al modelo del apoyo en la toma de decisiones, de manera que "las personas con discapacidad tienen capacidad de ejercicio en igualdad de condiciones en todos los aspectos de la vida" —artículo 3-. Si la discapacidad impide a la persona entender y querer lo que se le presenta a su entendimiento, será asistido por un apoyo para que autónomamente pueda tomar sus decisiones en la creación, modificación o extinción de relaciones jurídicas.

El apoyo no tiene facultad de representación, salvo en los casos en que se establezca expresamente por decisión de la persona con necesidad de apoyo o cuando el juez lo determine de modo excepcional - artículo 659-B-, cuando el discapacitado no pueda tomar decisiones por sí misma ni aun mediante apoyos. La ley no elimina la figura de la representación, sino que

67. LESCANO, Patricia. La guarda de hecho a la luz de la Convención de las Naciones Unidas sobre los Derechos de las Personas con Discapacidad. De los derechos a los hechos. En: La Convención Internacional sobre los Derechos de la Persona con Discapacidad, Op. Cit.

68. "Artículo 50. Ajustes razonables para personas con discapacidad. 50.1 La persona con discapacidad tiene derecho a ajustes razonables en el proceso de selección de recursos humanos y en el lugar de trabajo. 50.2 Los ajustes razonables en el proceso de selección comprenden la adecuación de las metodologías, procedimientos, instrumentos de evaluación y métodos de entrevista. En el lugar de empleo de las personas con discapacidad, los ajustes razonables comprenden la adaptación de las herramientas de trabajo, las maquinarias y el entorno de trabajo, incluyendo la provisión de ayudas técnicas y servicios de apoyo; así como la introducción de ajustes en la organización del trabajo y los horarios, en función de las necesidades del trabajador con discapacidad. 50.3 El Ministerio de Trabajo y Promoción del Empleo y los gobiernos regionales prestan asesoramiento y orientación a los empleadores para la realización de ajustes razonables para personas con discapacidad en el lugar de trabajo. Los empleadores públicos y privados generadores de rentas de tercera categoría tienen una deducción adicional en el pago del impuesto a la renta sobre los gastos por ajustes razonables para personas con discapacidad, en un porcentaje que es fijado por decreto supremo del Ministerio de Economía y Finanzas. 50.4 Los empleadores del sector público y privado están obligados a realizar los ajustes razonables, salvo cuando demuestren que suponen una carga desproporcionada o indebida, de conformidad con los criterios fijados por el Ministerio de Trabajo y Promoción del Empleo, que se aplican en el sector público y en el privado." —Texto modificado por Decreto Legislativo 1417, publicado el 13 de setiembre de 2018-.

69. Código Civil:

"Artículo 659-B. Definición de apoyos. Los apoyos son formas de asistencia libremente elegidos por una persona mayor de edad para facilitar el ejercicio de sus derechos, incluyendo el apoyo en la comunicación, en la comprensión de los actos jurídicos y de las consecuencias de estos, y en la manifestación e interpretación de la voluntad de quien requiere el apoyo.

El apoyo no tiene facultades de representación salvo en los casos en que ello se establezca expresamente por decisión de la persona con necesidad de apoyo o el juez en el caso del artículo 659-E. 
relega su aplicación residual para los casos más graves en los que el discapacitado no pueda manifestar su voluntad y resulte imposible la aplicación del sistema de apoyos.

Las personas con discapacidad cuentan con capacidad de goce y de ejercicio en igualdad de condiciones con las demás, en todos los aspectos de la vida. Las deficiencias físicas, mentales, intelectuales o sensoriales de que adolecen no les incapacita para gestionar sus asuntos, lo que pueden hacer con la ayuda de apoyos, sin eliminar o restringir su capacidad de obrar, sin la necesidad de ser sustituidos mediante representación. Solamente en casos que la discapacidad anule las facultades cognitivas y volitivas de la persona y la modalidad de apoyos resulte insuficiente para su protección, el juez les nombrará representante - tutor o curador- si se justifica, "después de haber realizado esfuerzos reales, considerables y pertinentes para obtener una manifestación de voluntad de la persona y de habérsele prestado las medidas de accesibilidad y ajustes razonables" - artículo 659-E-, a fin de asegurar el ejercicio y protección de sus derechos. En el proceso de nombramiento de representante, el juez oirá al discapacitado, valorará el alcance de sus facultades cognitivas y volitivas, para determinar si la persona no es capaz de tomar decisiones por sí misma y fijar los límites de la representación.
En el sentido del artículo 3 del Código, las personas con discapacidad tienen la misma capacidad de goce y de ejercicio, en igualdad de condiciones, que los demás, en todos los aspectos de la vida, debiendo la sociedad y el Estado erradicar los obstáculos que dificulten a los discapacitados su participación e inclusión plena en la sociedad, eliminando todos los obstáculos que lo impidan, mediante el establecimiento de ajustes razonables, apoyos y salvaguardias. Si a pesar de intentar rescatar la capacidad de ejercicio del discapacitado, existen situaciones muy graves que no lo permiten, se tendrá que recurrir a las figuras de la sustitución y representación, como última ratio y de acuerdo a las circunstancias concretas de cada persona.

Los apoyos y salvaguardias, figuras tuitivas de las personas con discapacidad, no sustituyen la voluntad del discapacitado sino les asiste en el ejercicio de su capacidad de ejercicio. Para impedir los abusos de los apoyos se establecen salvaguardias que son, como lo señala el artículo 659-G del Código, inspirado el artículo 12.4 de la Convención,

"medidas que garantizan el respeto de los derechos, la voluntad y las preferencias de la persona que recibe apoyo, prevenir el abuso y la influencia indebida por parte de quien brinda tales apoyos; así como evitar la afec-

Cuando el apoyo requiera interpretar la voluntad de la persona a quien asiste aplica el criterio de la mejor interpretación de la voluntad, considerando la trayectoria de vida de la persona, las previas manifestaciones de voluntad en similares contextos, la información con la que cuenten las personas de confianza de la persona asistida, la consideración de sus preferencias y cualquier otra consideración pertinente para el caso concreto."

"Artículo 659-E. Excepción a la designación de los apoyos por el juez. El juez puede determinar, de modo excepcional, los apoyos necesarios para las personas con discapacidad que no puedan manifestar su voluntad y para aquellas con capacidad de ejercicio restringida, conforme al numeral 9 del artículo 44. Esta medida se justifica, después de haber realizado esfuerzos reales, considerables y pertinentes para obtener una manifestación de voluntad de la persona y de habérsele prestado las medidas de accesibilidad y ajustes razonables, y cuando la designación de apoyos sea necesaria para el ejercicio y protección de sus derechos.

El juez determina la persona o personas de apoyo tomando en cuenta la relación de convivencia, confianza, amistar, cuidado o parentesco que exista entre ella o ellas y la persona que requiere apoyo. Asimismo fija el plazo, alcances y responsabilidad del apoyo. En todos los casos, el juez debe realizar las diligencias pertinentes para obtener la mejor interpretación posible de la voluntad y las preferencias de la persona, y atender a su trayectoria de vida. No pueden ser designados como apoyos las personas condenadas por violencia familiar o personas condenadas por violencia sexual. 
tación o poner en riesgo los derechos de las personas asistidas".

Como lo señala la Convención en el artículo 12 , las salvaguardias deben ser proporcionales y adaptadas a sus circunstancias de la persona del discapacitado, se aplicarán en el plazo más corto posible y estarán sujetas a exámenes periódicos por parte de una autoridad o un órgano judicial competente, independiente e imparcial. En este marco convencional, el párrafo final del artículo 659-G prescribe: "El Juez realiza todas las audiencias y diligencias necesarias para determinar si la persona de apoyo está actuando de conformidad con su mandato y voluntad y preferencias de la persona".
Es obligación del Estado, haciendo los ajustes necesarios en sus leyes y políticas, adoptar todas las medidas pertinentes y efectivas para permitir que las personas con discapacidad puedan alcanzar su libertad para realizarse como personas con plenos derechos. Se les debe asegurar a los discapacitados el ejercicio de su plena capacidad de goce - que en esencia es una atribución del Derecho a todo ser humano para realizarse como tal- en las mismas condiciones con las demás personas, para que puedan disfrutar de sus derechos en igualdad de oportunidades, asegurándoles su no discriminación, a cuyo fin se les debe dotar de los apoyos y salvaguardias que necesiten, de acuerdo a sus circunstancias concretas y personales. 